\title{
Lives and Afterlives of an Urban Institution and Its Spaces: The Early Ottoman İmāret as Mosque
}

\author{
Çiğdem Kafescioğlu
}

Since the architect and restorer Sedat Çetintaş argued in 1955 that "the Green Mosque and its likes are not mosques"1 the identity and functions of the buildings he was referring to, namely the "T-type" structures that are among the most distinctive products of early Ottoman architectural culture, have been matters of debate. These edifices, widely dispersed in late medieval northwestern Anatolia and the Balkans and patronized in the early centuries largely by sultans and military leaders of the frontier zones, had plural accommodative, social, and devotional uses. They were planned around a domed central hall, with flanking rooms and an eyvān (Ar. $\bar{w} w \bar{a} n$ ) across the entrance beyond the domed hall. The eyvān, a vaulted or domed hall that opens to the central domed space and is elevated by a few steps, was in most, but not all cases allocated to prayer. Their foundation deeds (waqfiyya) identify them as imāret or zāviye (Ar. zāwiya), and their users as "comers and goers" (an expansive range of people in the tempestuous worlds of medieval Anatolia and Balkans), traveling dervishes, and the needy; in royal foundations, ulama, shaykhs, sayyids (sādāt), Quran readers, and preachers are recounted among beneficiaries. Their waqfyyas make clear that the offering and consumption of food, social and religious ritual, and shelter provided to dervishes and travelers intersected in these buildings constructed outside the established urban cores, initially of Bithynian and Thracian cities. ${ }^{2}$ The oft-cited travel narrative of the North African scholar Ibn Battutua corroborates this and offers a vibrant view into the conviviality that formed the texture of life in Anatolian zāviyes. ${ }^{3}$ As far as modern

1 Çetintas, Yeşil Camive benzerleri. The booklet is the publication of a lecture the author delivered in 1955 at the Faculty of Theology of Ankara University. The reference is to the Green Mosque in Bursa, Turkey.

2 Gökbilgin, Murad I, 225-231; Ayverdi, Yıldırım Bayezid'in, 37-46; Zengin, İlk dönem Osmanl,, 114-117.

3 Ibn Battuta, The travels, $419 \mathrm{ff}$. Ibn Bațuṭa's comments on Anatolian zāviyes as communal spaces of urban confraternities $(a h \bar{\imath})$ has raised the question of the relationship between $a h \bar{\imath}$ and Sufi lodges in medieval Anatolia, an issue that has not been resolved. Oya Pancaroğlu quotes Suhrawardī's comments on Sufi lodges being founded by rulers and futuwwat-khānas 
scholarship on these buildings is concerned, however, it has proven difficult (if not impossible) to eliminate, or even to de-emphasize the notion that they functioned primarily as mosques. ${ }^{4}$

The difficulty in establishing a historicized understanding of the Ottoman "T-type" buildings is in part due to the nature of the changes in the buildings' architecture, uses, and institutional designations (and the degree to which these have, or have not, been addressed by architectural historians). Equally significant are the connections between architectural and institutional configurations to shifts in Ottoman religious politics. Starting in the 910s/1510s, and more visibly in the middle and later decades of the tenth/sixteenth century, the majority of Ottoman imärets, which powerfully announced their patrons' benefaction through their offering of food, shelter, and ritual space, were turned into congregational mosques, the primary type of religious structure sponsored by Ottoman patrons, especially through what has been regarded their "classical age." In other words, the larger part of Ottoman imärets/zäviyes, and among them those well-known structures built by sultans as part of prestigious building complexes at the edges of such cities as Bursa and Edirne, have functioned as congregational mosques beyond about the first century and a half (in fewer cases the first two centuries) of their lives as public edifices. As much as Sedat Çetintaş was correct in his assertion, Yeşil Cami had been a mosque for about 400 years at the time he made his emphatic statement on the building's former identity (figures 8.1, 8.2). ${ }^{5}$

The disjunction between historical and modern terminologies used to denote these edifices, too, captures and continues to reproduce the historio-

by masters; she also calls attention to ahīs mentioned in the waqfiyya of Bāyezīd I's Bursa foundation; Pancaroğlu, Devotion, hospitality. İklil Selçuk discusses the issue from the point of view of economic activities and connections of the $a h \bar{\imath}$ communities and their mediation in linking urban and rural communities; Selçuk, Suggestions on the social meaning. See also the note on Evrenosoğlu İsā Bey's Skopje 'imāret below. On urban confraternities in medieval Anatolia, see Goshgarian, Beyond the social and the spiritual. Zāviyes have also been interpreted as having a role in early Ottoman colonization, Barkan, Osmanlı İmparatorluğunda; Emir, Erken Osmanlı mimarlığında; Boykov, The T-shaped zaviye/imarets. Colonization is not a concept I draw on in the present study.

4 Most general works on Ottoman architecture have prioritized the mosque function of the T-type buildings. For works that have prioritized the plural uses of the 'imāret/zāviye, see Sedat Emir, Erken Osmanlı mimarlığında; Emir, Erken Osmanlı mimarlığında; Kuban, Osmanlı mimarisi 81-247; Oğuz, Multi-functional buildings; Lowry, The shaping 65-106; Çağaptay, Frontierscape; Pancaroğlu, Devotion, hospitality.

5 Çetintaş identified the T-type structures as zāviyes in his 1946 book Türk mimari anıtları; he argued in the 1958 lecture publication that the side rooms of these buildings had official functions, such as court rooms for kadis. 


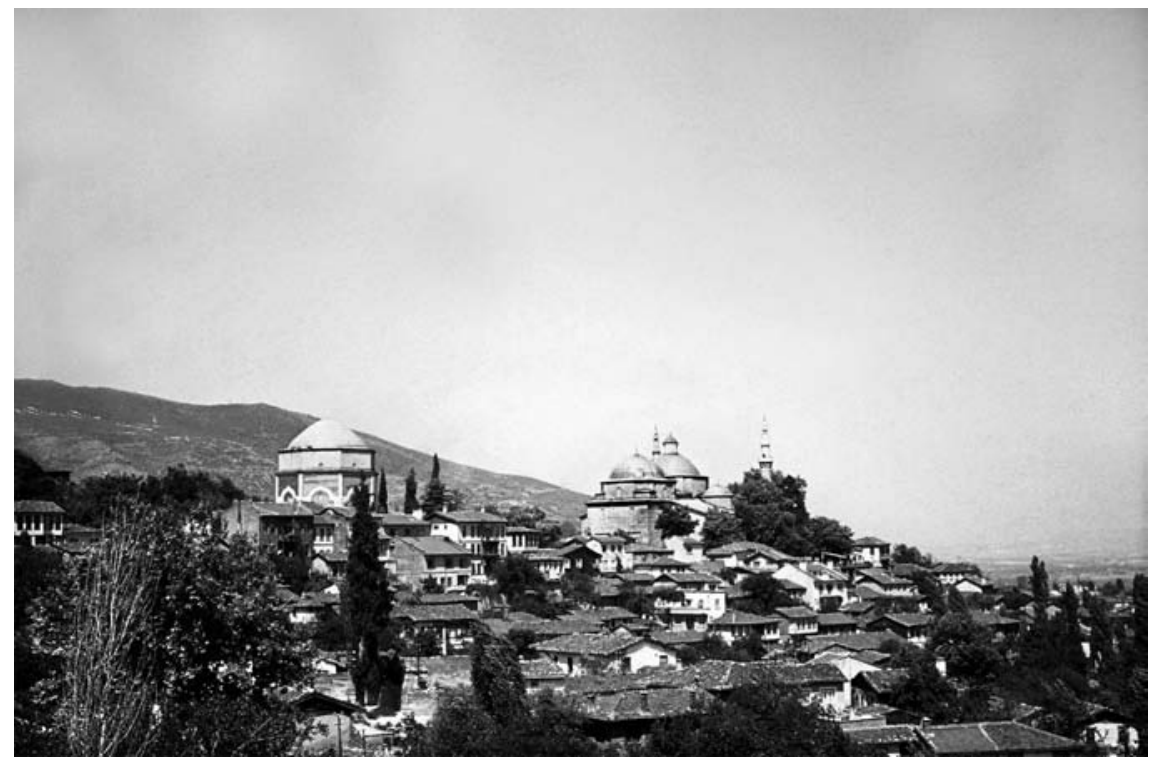

FIGURE 8.1 Bursa, zāviye/ 'imāret and complex of Mehmed I, the "Green Mosque," 822/1419 BY PERMISSION OF THE BOĞAZIÇI UNIVERSITY APTULLAH KURAN ARCHIVE

graphic quandary. Inscriptions, foundation deeds, historical narratives, and archival documents identify them with terms that connote Sufi ritual, the offering of shelter, and the daily and ritual consumption of food. Often the same building is identified in different documents as 'imāret, zāiviye, or hānkāh (the latter two referring more specifically to spaces of ritual and accommodation of Sufi groups and ahì confraternities); buk'a (a place, spot, or building) and dāra hayren (place of charity) are also terms one encounters in documents and inscriptions. ${ }^{6}$ These terms are encountered often in documents of representational nature for the edifices in question, and the choice of terms, 'imāret in most inscriptions and zavivie in the greater part of foundation deeds (and their interchangeable use with other terms), appears to be less than accidental. Hence, the foundation of Orhan $(724-763 / 1324-1362)$ in Bursa is "zāviye, known among people as "imāret" in its waqf document and "imāret in its restoration inscription dated 820/1417, highlighting the larger public recognition of the buildings as 'imāret. ${ }^{7}$ In similar fashion, Murād I's (763-791/1362-1389) waqfiyya

6 The buildings have most frequently been termed zāviye, alongside buḱ 'a, hānkāh or 'imāret in waqf documents, and 'imāret in most foundation inscriptions. A comprehensive list and discussion of terms denoting the buildings in various documents is found in Emir, Erken Osmanlı mimarlığında 270-272 and passim. See also Tüfekçioğlu, Erken dönem Osmanlı.

7 The original $761 / 136$ o waqf document has not survived, but a copy dated 896/1491 is available; see Ayverdi, Osmanlı mi'marisinin i, 63-65. 


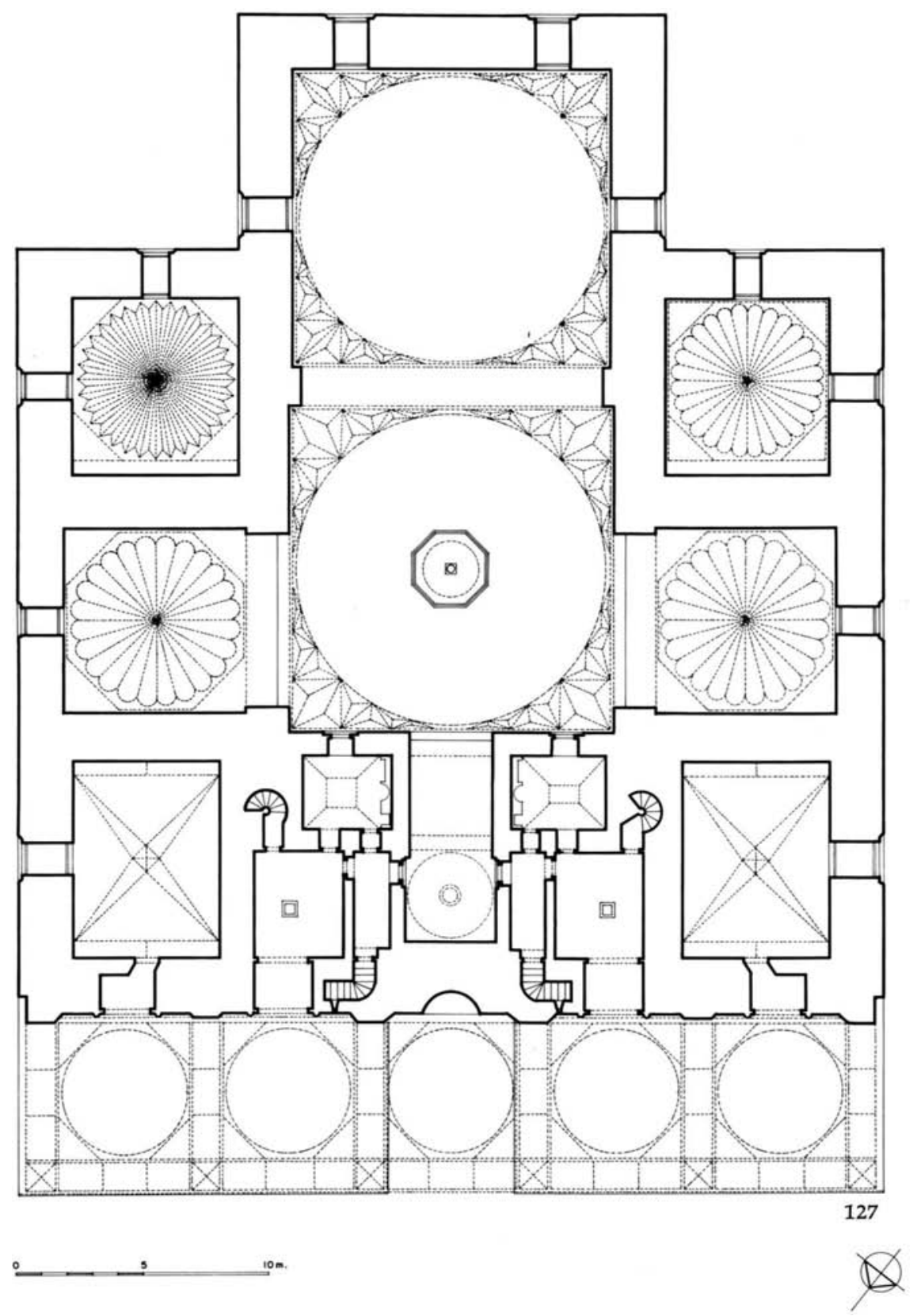

FIGURE 8.2A Bursa, zāviye/'imāret of Mehmed I, 822/1419, plan BY PERMISSION OF THE BOĞAZIÇI UNIVERSITY APTULLAH KURAN ARCHIVE 


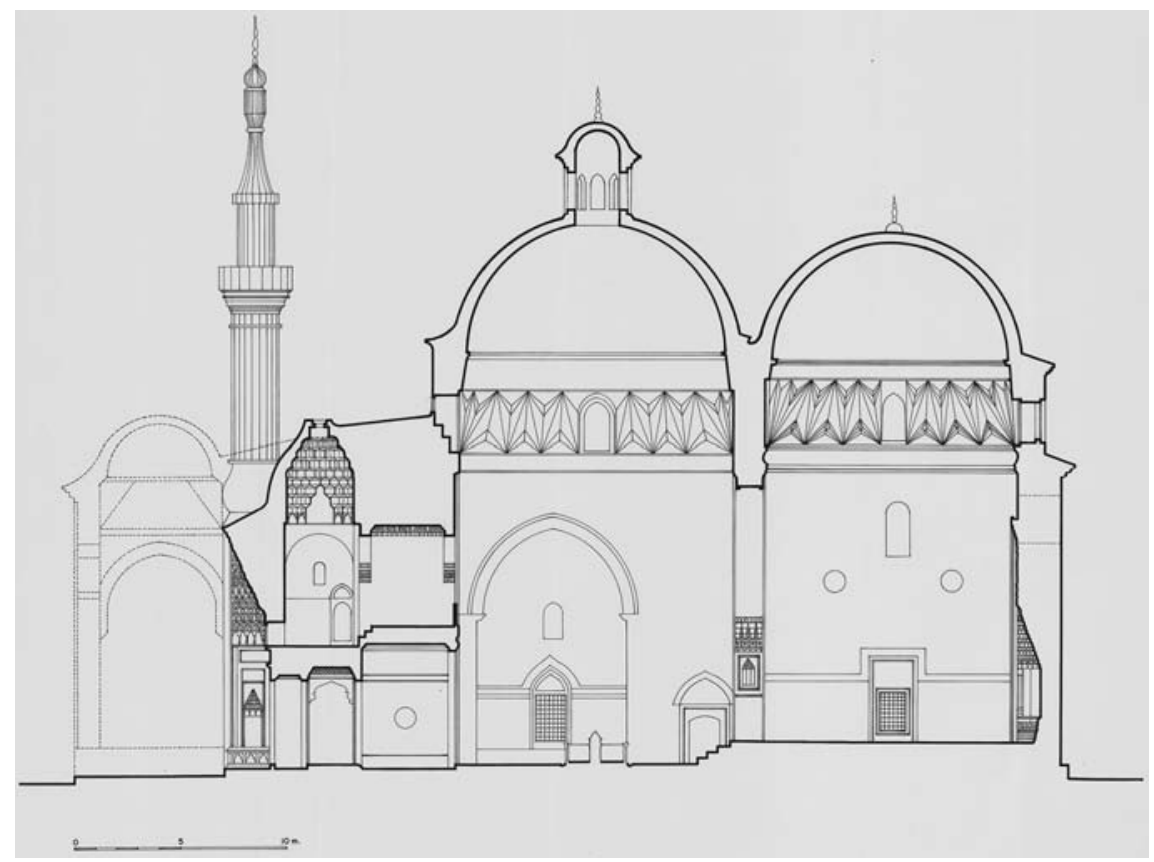

Figure 8.2B Bursa, zāviye/'imāret of Mehmed I, 822/1419, section BY PERMISSION OF THE BOĞAZIÇI UNIVERSITY APTULLAH KURAN ARCHIVE

for the building he founded in Bursa's Çekirge suburb identifies it as "the zāviye called Kaplıca 'imāret;"8 Mehmed I’s (816-824/1413-1421) Bursa foundation is called buk'a and 'imäret in two inscriptions dating to 822/1419 and 827/1424 respectively, and zāviye in its waqf document of $822 / 1419 .{ }^{9}$

However divergent their interpretations of the uses, historical and geographical horizons, and formal configurations of the early Ottoman 'imāret, many modern scholars have formulated, or preferred to use, terms that have underscored these buildings' function as prayer spaces: hence, Bursa-type mosque, zaviye and zaviyeli cami (mosque with a zāwiya), tabhaneli cami (mosque with hospice rooms), eyvān mosque, and futuwwa mosque. ${ }^{10}$ The term "convent-

8 BOA, Maliyeden Müdevver 162/5; Gökbilgin, Murad I 225.

9 Ayverdi, Çelebi 5 o.

10 The term Bursa-type mosque was suggested by Wilde in his Brussa. A pioneering study that called attention to the social uses of the buildings is Eyice (who noted that his work was inspired by that of Çetintaş), Illk Osmanlı Devrinin. Kuran, The mosque presented a formal categorization and analysis of the type. Recognizing the multifunctional character of the buildings, Kuran highlighted the masjid function of the qibla eyvān, hence proposed 
masjid" offered by Gülru Necipoğlu for those buildings that have a masjid eyvān - that is, an eyvān that functioned as a designated place of prayer oriented toward Mecca-highlights their plural uses, while it attributes equal weight to the masjid and convent functions of the building. ${ }^{11}$ Reviewing terminological choices, one may also consider that medieval Syrian and Cairene madrasas and hānkāhs, and their Anatolian contemporaries, more often than not featured a prayer space with a mihrab, and have not been termed masjid or mosque in contemporary sources or in modern scholarship. ${ }^{12}$

This paper approaches the set of questions posed by this distinct product of late medieval architecture from the point of view of the time of change noted above: the period encompassing the later decades of the ninth/fifteenth into the later decades of the tenth/sixteenth century, which turned 'imāret and $z \bar{a} v i y e$ into mosque (whether these were extant buildings that underwent processes of conversion or newly built edifices that followed the distinguishing conventions of the T-type edifice). Within the same time frame, the 'imäret was produced and reproduced as a new kind of space and in part, a new notion: now it also denoted the soup kitchen built as an independent structure within a larger compound. I locate the beginnings of that shift in the mid-86os/146os and $870 \mathrm{os} / 47 \mathrm{os}$, that is, the decades of the first, and most intense phase of new construction in Istanbul by the Ottoman elite. During these years the vast building complex founded by Mehmed II (r. 848-850/1444-1446, 855-886/1451-1481) in newly conquered Istanbul, followed by a set of viziers' foundations within the walled city— to be discussed in detail below-radically altered the uses and meanings of the urban foundation as it had taken shape through the eighth/fourteenth century. While they were still conceived as tools of settlement and loci of symbolic representation, sultanic and elite endowments of the imperial age were products of a newly formulated religiopolitical configuration, which effected changes in terminology, in institutional practices, and in spatial and visual configurations. The agency of the new elite of slave origins

the term "eyvān mosque." The term "futuwwa-mosque" was suggested by Doğan, Osmanlı Mimarisinde. For historiographic discussions, see Emir, Tipoloji; Çağaptay, Frontierscape 162-166; Yürekli, Architectural patronage 734-735. See also Ergin, Neumann and Singer, Introduction, in Feeding people 22-28.

11 Necipoğlu, The age of Sinan 48-5o. I have used this designation in Constantinopolis/Istanbul. In Ottoman usage, cāmic (Ar. jāmic) designated a congregational mosque, while masjid denoted a small prayer space, whether free standing or attached to another building, with no allowances for a $h a t i ̄ i b$ (Friday preacher), and by extension, for the delivery of the Friday sermon.

12 As noted by Emir, Tipoloji 121. 
empowered by Mehmed II to replace a former elite and to counter the power of the frontier lords was central to this process.

\section{$1 \quad$ History, Typology, and a Passage into Early Modernity}

The immediate historical and methodological questions with regard to the topic of this paper are the spatial, institutional, and architectural dimensions of a passage: one may broadly define this as a transition from a set of medieval religious, institutional, and spatial practices to one in tune with the workings of an early modern polity and society. The product of an age of cultural dynamism and fluidity, a comparatively more diffuse and fluid set of signifying practices shaped the 'imāret building and its institutional setup. ${ }^{13}$ The layout of the Ttype edifice, whether it was founded as and called a zāviye, an 'imāret, a buk'a, or a $h \bar{a} n k \bar{a} h$, imposed no absolute boundaries between spaces of the sacred and the profane; likewise, their foundation documents, though with substantial differences across geography and patronage profiles, do not stipulate distinctions regarding ritual practices within. The moment of change in the histories of Ottoman imāret and mosque (with implications for the larger urban environment) can be firmly located in the final quarter of the ninth/fifteenth century. The histories of these institutions and the changes in their architecture are intricately linked to long-term religiopolitical processes that rendered the establishment of orthodox Sunni doctrine and practice a priority: dynamics that reached their powerful articulation during the reign of Süleymān (r. 926-974/1520-1566). ${ }^{14}$ As unwelcome as it might have been in the frontier environment that gave shape to the early Ottoman 'imāret, then, I will be bringing

13 On the early Ottoman political and cultural context, see Kafadar, Between two worlds; on politico-religious dynamics of the lands of Rum in the late medieval era, see Krstić, Contested conversions 26-74. On architectural culture of medieval Anatolia with particular attention to fluidity of forms and identities and to practices of devotion and conviviality, see Pancaroğlu, Devotion, hospitality. On medieval Anatolian madrasas and hānkahs, the closest forerunners to the early Ottoman 'imāret, see Kuran, Anadolu medreseleri; Wolper, Cities and saints; Emir, Erken Osmanlı i; and Pancaroğlu, Hospitality, devotion. A comparable transposition between madrasa and khanqah in Mamluk Cairo has been explored in Behrens-Abouseif, Change in function and form.

14 For explorations into Ottoman Sunnitization and within a larger framework, confessionalization, see Terzioğlu, How to conceptualize; Terzioğlu, Where ilm-i hạal meets; Krstić, Contested conversions; Krstić, Illuminated by the light; Krstić, From shahada to 'aqida. See also Burak, Faith, law, and empire. On trends toward Sunnitization interconnected with tenth/sixteenth-century Ottoman architectural culture, see Necipoğlu, The age of Sinan, esp. $47-58$. 
into the picture the heavy hand of a centralizing state in the making, redefining political hierarchies and formulating religious orthodoxy, to alter, co-opt, and within the course of a century definitively marginalize a set of medieval spatial practices predicated on long-nurtured and well-understood multiplicities and ambiguities.

There is perhaps a correspondence between the early modern insistence on transforming urban 'imärets exclusively into mosques and the modern insistence on a distinct name and function to be attached to these buildings. Granted, sixteenth-century religious politics and twentieth-century disciplinary predilections belong to distant epistemic spheres, with the desire to establish a singular, state-sanctioned use (mosque) for edifices with multiple identities, on one hand, and the desire to nail down the specifics of their multifunctionality, on the other. However, they do partake of a mental world focused upon classifying and identifying difference, as Sanjay Subrahmanyam has observed, ${ }^{15}$ connecting an early modern state's desire to dictate norms and regulate practices to the modern academy's urge to categorize and define.

An exploration of the early Ottoman 'imāret from the perspective of its afterlives in early modern and modern times also brings forth questions regarding typology and temporality in the study of architecture. The expansive range of structures that architectural historians have treated as a type (regardless of what terminology they have opted for), and the deliberate changes these structures were subjected to, whether in the form of interventions to extant buildings or spatio-visual alterations in the established configuration when new buildings were designed, unveils the quandaries of working within a conceptual frame determined by typology. Differences in the formal and institutional configuration of 'imärets within the Rumi space need to be considered as well. Sharing a specific spatial and volumetric composition and interconnected through a particular patronage profile, early Ottoman 'imārets served a range of functions in various loci and communicated related but distinct meanings in frontier environments as opposed to in centers like Amasya and, into the later eighth/fourteenth century, Bursa. Hence the T-type includes structures like the Evrenos 'imäret in Komotini, centered on an eyvān that opens directly onto an exterior court with no portal or portico, Bāyezīd I's Edirne 'imāret, with its atypical layout and unresolved questions regarding its construction history, and the Postinpūş Baba zāviye built by Murād I for this dervish in Yenişehir, with a single ceremonial hall flanked by rooms, none of the three buildings having qibla orientations. The differences between these buildings and others like the Bāyezīd 
Pasha imāret in Amasya (one among a number of analogous structures), the celebrated royal 'imārets of Bursa with their prominent masjid eyvāns, or Rūm Mehmed Pasha's Byzantinizing mosque and hospice in Üsküdar, Istanbul, highlights the problems of typology as a historian's tool on the one hand, and the particular issues connected to this "type" on the other (figure 8.3). ${ }^{16}$ The terminological and historiographical problem arises, in part, from the use of the same frame of reference to understand the initial making and later refashioning and reinterpretations of the early Ottoman 'imäret, whose functions and symbolic associations rendered it worth reproducing and revisiting through changing cultural contexts between the earlier eighth/fourteenth and the earlier tenth/sixteenth centuries. Evidently, continued reference to the "type" also required radical modifications. ${ }^{17}$ Mapping out the histories of the foundation, uses, and reuses of 'imārets boldly highlights ruptures, continuities, and transformations in their identities as urban institutions, and in changing practices of signification that invested them (and alongside them, the mosque and the soup kitchen) with new meanings.

Foregrounding typology in the study of architectural history does pose the risk of presenting as stable what was in fact a set of processes of change, and this is a particularly pressing issue given the radical cultural and functional transformation that reshaped and redefined the meanings and uses of the early Ottoman 'imāret. At the same time, keeping questions of typology in view may be beneficial for this inquiry. The adherence to a "type," that is, a particular formal structure and a set of principles and choices that give shape to it, offers subsequent users the potential of drawing on the past in specific ways, for the choice may serve as a mode of reifying and reaffirming memory. Patrons and designers may reshape and reinvest the type, while at the same time projecting architectural, and by extension, social stability and continuity through their adherence to it. ${ }^{18}$ Typology, for this inquiry, then, is not completely without significance: rather than the ahistorical schematization it offers, its interest lies

16 On the Evrenos 'imāret, see Kiel, The oldest Ottoman monuments; Lowry, The shaping 8o-84; Çağaptay, The road from Bithynia, where she also discusses issues of typology. On Postinpūş Baba, and Bāyezīd I's Edirne 'imāret, see Ayverdi, Osmanlı mi'marisinin i, 208-216, 484-494, Kuran, Edirne'de Yıldırım camisi; Kuban, Osmanlı mimarisi 85; on Rūm Meḥmed Pasha, see Kafescioğlu, Constantinopolis/Istanbul, 119-122. On the Bāyezīd Pasha imāret completed in 1419, see Kuran, The mosque 82-85. On shifts in patronage profiles and contexts of construction, see Oğuz, Multi-functional buildings.

17 Shifts in architectural meaning in connection to historical change have been addressed in a set of diverse contexts in Arnold and Ballantyne, Architecture as experience 1-10; and Ballantyne, Misprisions of Stonehenge.

18 Rossi, Architecture of the city 35-45; see also Koch, Changing building typologies. 


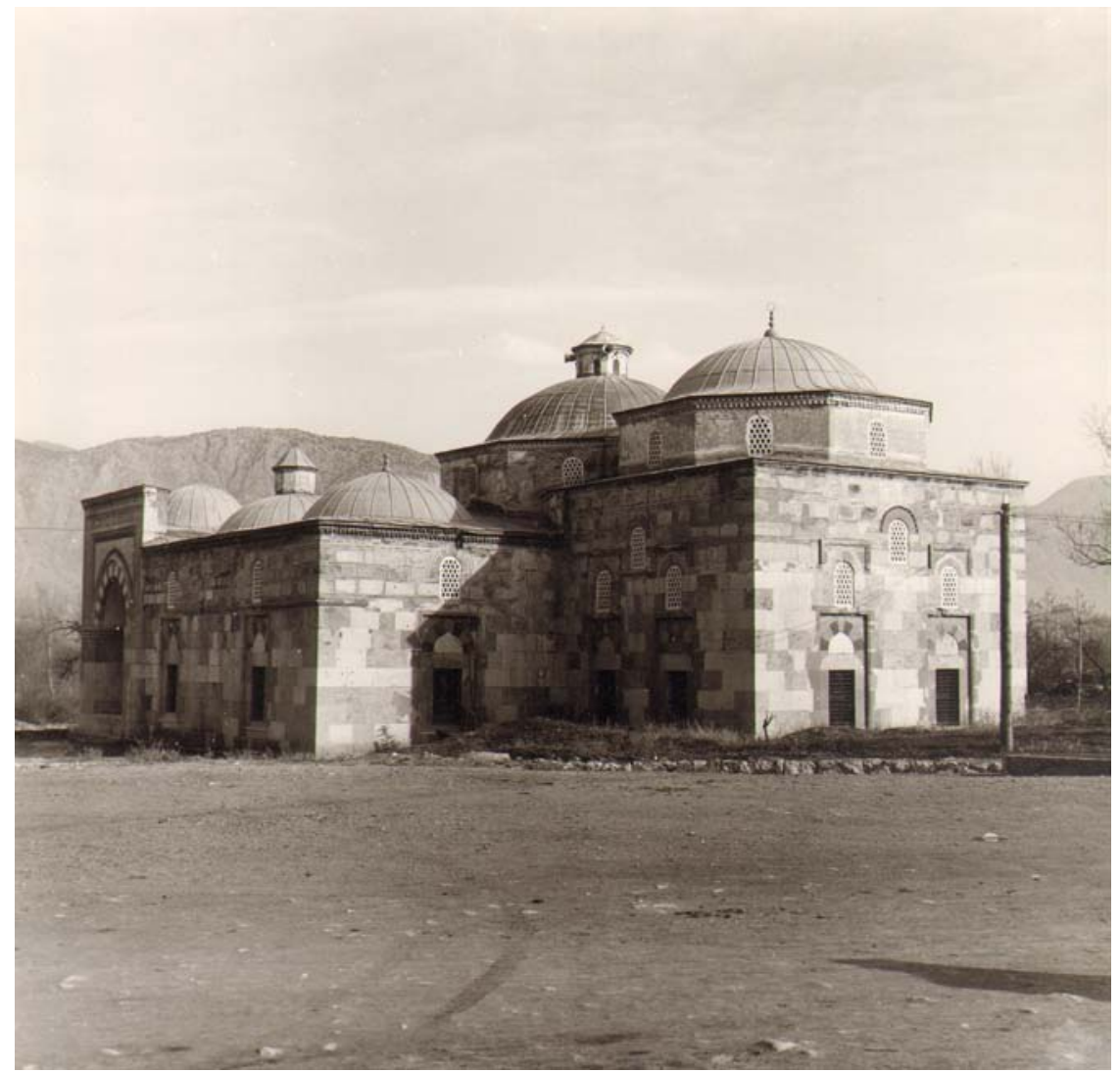

FIGURE 8.3 Amasya, Bāyezīd Pasha zāviye/'imāret, 817/1414

BY PERMISSION OF THE BOĞAZIÇI UNIVERSITY APTULLAH KURAN ARCHIVE

in the light it may shed on the significance of the imäret as a type for the patrons, builders, and users of shifting historical, political, and religio-cultural contexts.

In this paper I opt for using the term 'imäret interchangeably with zāviye, while I grant that the first term in particular poses a set of problems. Inscriptions, waqf documents, and narrative sources suggest that up to the final resolution of the transformation that turned frontier polity into centralizing empire, the 'imāret in the Ottoman domains was specifically the accommodative structure laid out in a reverse-T configuration around a central domed hall, at a distance to the urban center and often outside of the inhabited area. It may or may not be the centerpiece of a set of service structures and other buildings, such as a madrasa, a bath, or the founder's tomb. As a medieval legacy of the larger Islamic world, 'imāret may also denote any building project of a sub- 
stantial nature, most often public, at times also private. A further dimension of the terminological puzzle is that during the early modern era 'imarret came exclusively to denote two functions at once: the urban socioreligious building compound and the soup kitchen that may be among the buildings of such a compound..$^{19}$ This semantic shift and the projection of the latter meaning backward onto the eighth/fourteenth and early ninth/fifteenth centuries has led to a degree of confusion in modern scholarship on early architectural ventures in the Ottoman domains. The imärets mentioned in waqf documents alongside substantial kitchen expenses have been taken as evidence for the presence of a separate building that was part of a building complex, imagined to resemble later soup kitchens in the Ottoman domains. ${ }^{20}$ In a more recent body of work, many early 'imāret buildings have been considered exclusively as soup kitchens. ${ }^{21}$ Evidence for the material and spatial setup of the service sections of the early Ottoman complexes, however, is scant. That the täbhāne (hospice) rooms located to the two sides of the 'imäret's main domed hall served also as places where food would be served can be conjectured. What remains of the kitchen, storage, and refectory spaces (and the fact that so little does remain of the original forms of such structures anywhere within the Ottoman domains, whether the buildings were sponsored by sultans or by frontier lords), on the other hand, strongly suggest that these were not regarded as representational buildings by their patrons and were rather built with less durable and less prestigious materials and workmanship. Among the few structures whose remnants survived into the twentieth century, the kitchen and (possibly) refectory structures of Murād II's (r.824-848/1421-1444; 850-855/1446-1451) Bursa complex may be noted: situated a few meters away from the imāret, rectangular spaces of rubble masonry and timber roofs as captured by Albert Gabriel in his Brousse, or the reconstructed kitchen and refectory of the Mehmed I complex speak to the same attitude (figure 8.4). However important food and food related rituals were to the representational agendas of sultans and $g \bar{a} z \bar{\imath} \mathrm{s}$, it was

19 Past the early decades of the tenth/sixteenth century, the foundation of a soup kitchen became a royal prerogative of sultans and dynastic women, with few built by viziers in provincial cities or on way stations. On changes in the meaning of 'imäret in the Ottoman context, see also Budak, İmaret kavramı üzerinden.

20 Hence the numerous notes in Ayverdi's surveys of early Ottoman architecture, and other studies often based on him, on the "absence" of the "imāret from many foundations at the time he surveyed the buildings. In most of these cases, the main building denoted as imāret in the document continues its existence as a mosque, while the service buildings connected to kitchen functions have not withstood time.

21 Singer, Imarets. See also Ergin, Neumann and Singer, Introduction; and Singer, Mapping imarets $13-39,43-55$. 


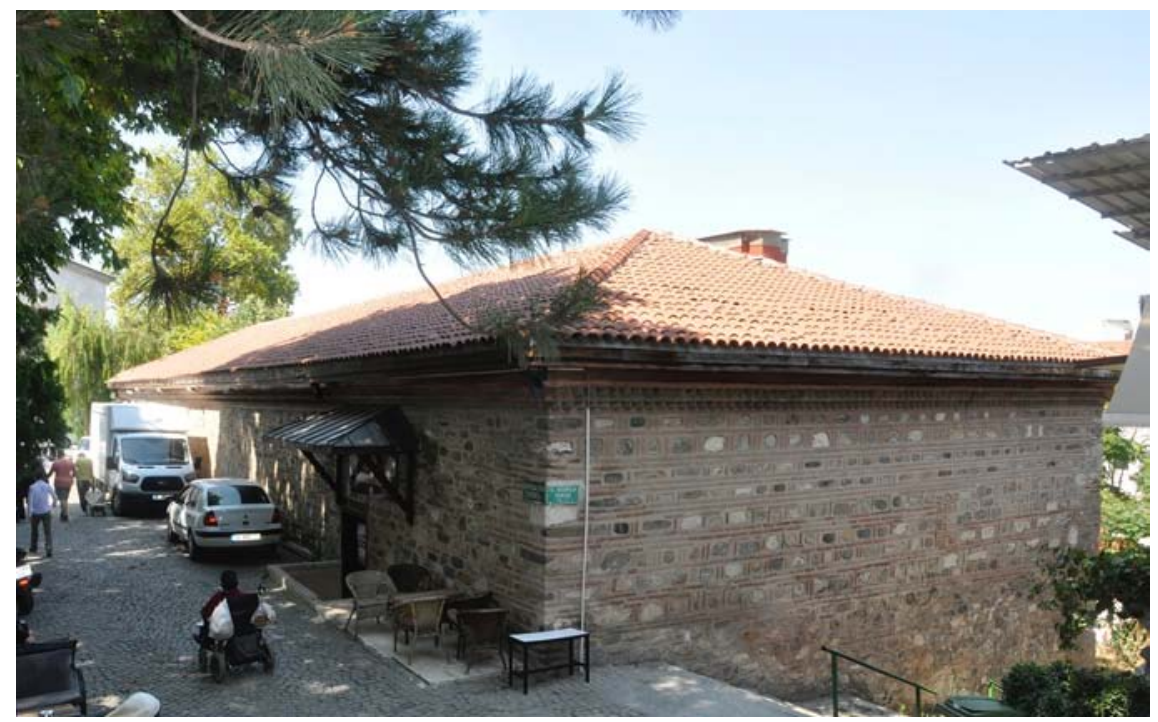

FIGURE 8.4 Bursa, kitchen and refectory of the Mehmed I complex PHOTOGRAPH BY THE AUTHOR

the multifunctional 'imāret/zāviye building, and not the kitchen or a separate refectory, that architecturally symbolized their acts of benefaction and their sheltering of conviviality. ${ }^{22}$

The study of the late ninth/fifteenth- and early tenth/sixteenth-century versions of the T-type building, too, presents a set of historiographic questions. Prompting lukewarm responses on the part of architectural historians, these buildings have been considered as late, sometimes unusual and not completely successful examples of an established typology. ${ }^{23}$ Within the evolutionary narrative of Ottoman architecture, marching from the relative modesty of its beginnings toward its stylistically unified and spatially centralized monumentality, in other words toward its celebrated "classicism," buildings such as Maḥmūd Pasha's (d. 878/1474) 'imāret-and-mosque in Istanbul, alongside many

22 Gabriel, Brousse 129, figure 72. A number of kitchen (mațbah) and refectory (me'kel) structures were rebuilt and expanded in later centuries, such as those of Orhan in 1145/1732 and Murād I in Bursa in 1045/1635, Ayverdi, Osmanlı mimarisinin i, 66, 234; Emir, Erken Osmanlı ii, 27-29. The references to "the mosque's lead covering and 'imāret's roof tiles" in a 1082/1671 court document subsequent to the conversion of Bāyezīd I's T-plan building into a mosque is of note, indicating that 'imarret at that time denoted the separate kitchen and refectory building; Ayverdi, İlk Osmanlı i, 423.

23 See, for example, Ayverdi, Fatih devri 433-451, for his evaluation of the Mahmūd Pasha mosque. 


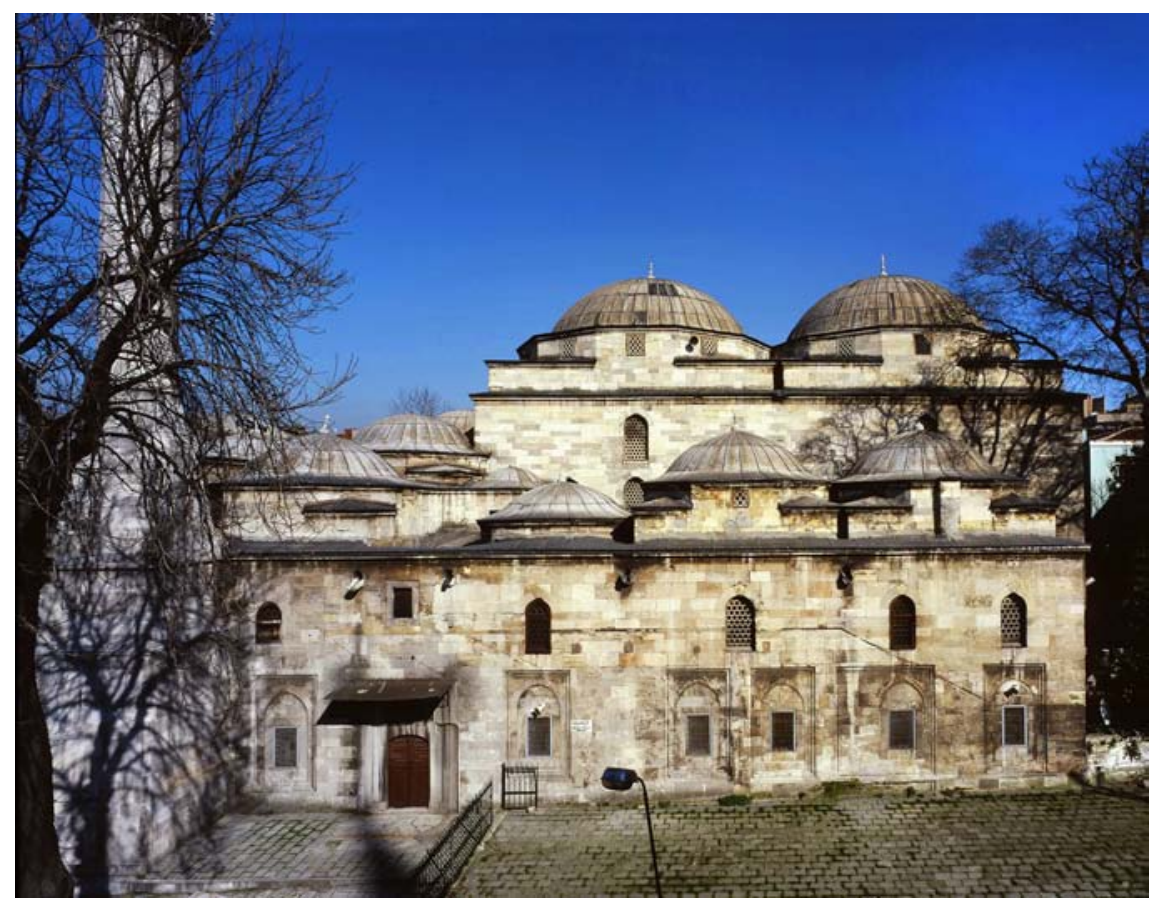

FIGURE 8.5 Istanbul, 'imāret and mosque of Maḥmūd Pasha, 878/1473-1474, exterior view.

Note the side entrance

PHOTOGRAPH FROM KAFESCIOĞLU, CONSTANTINOPOLIS/ISTANBUL

others within the imperial domains, have often been regarded as transitory structures that signified the gradual abandonment of an earlier order of partitioned interiors and constituted steps toward the prescribed goal of spatial centralization. The result has been that these buildings, hospice-and-mosque structures in and beyond Istanbul, and the politico-religious process that gave shape to them have attracted little attention (figures 8.5 and 8.6). ${ }^{24}$

I must briefly discuss the well-known, but nevertheless most telling facet of the shift in politico-religious orientations that informed the reshaping and redescription of the 'imäret: Mehmed II's socioreligious complex, rising during the 86os/146os on the hill that had previously supported the Church of the Holy Apostles and its dependencies (figure 8.7) ${ }^{25}$ Here, rather than a royal complex

24 Emir, Erken Osmanlı mimarlığında; Kafescioğlu, Constantinopolis/Istanbul, 109-130; Necipoğlu, The age of Sinan, $5^{2-55}, 9^{2-95}$.

25 On Mehmed II's mosque and complex within its broader contexts, see Necipoğlu, The age of Sinan, 83-88; Kafescioğlu, Constantinopolis/Istanbul, 66-96. 


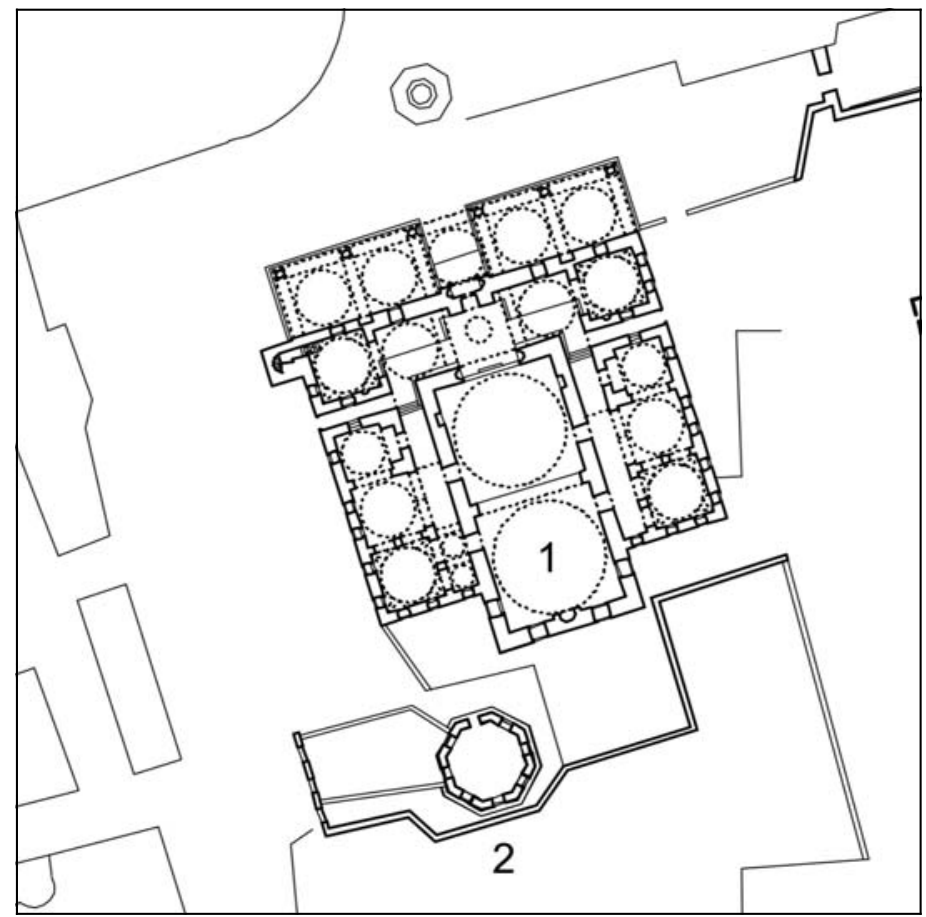

FIGURE 8.6 Istanbul, 'imāret and mosque of Maḥmūd Pasha, 878/14731474 (1. 'imāret and mosque; 2. mausoleum)

PLAN FROM KAFESCIOĞLU, CONSTANTINOPOLIS/ISTANBUL

centered by a zāviye that featured a prayer space, Mehmed II founded a congregational mosque with a novel design. The building was emphatically separated from any accommodative and service functions by the huge plaza surrounding it, measuring 200 meters to each side and referred to as meydān (square) or șahn (court) in contemporary sources. The meydān was aligned on two sides with the semaniye madrasas, a college compound conceived and built in an expansive scale unseen in the medieval Islamicate world, meant to educate the ulama of the imperial polity. Beyond that plaza and its surrounding wall was a new type of building: this is the very first royal imäret of the early modern era, a compound designed as a unit within its own walled enclosure, including a courtyard structure that housed the soup kitchen and rooms for travelers, a caravanserai, and a refectory for madrasa students. The rich endowment, impressive architecture, prestigious building materials, and craftsmanship of Mehmed II's 'imāret marks a turning point in the dynasty's architectural ventures. While Mehmed II and his architects made the Friday mosque the physical and institutional center of the royal compound, the visual and aesthetic dis- 


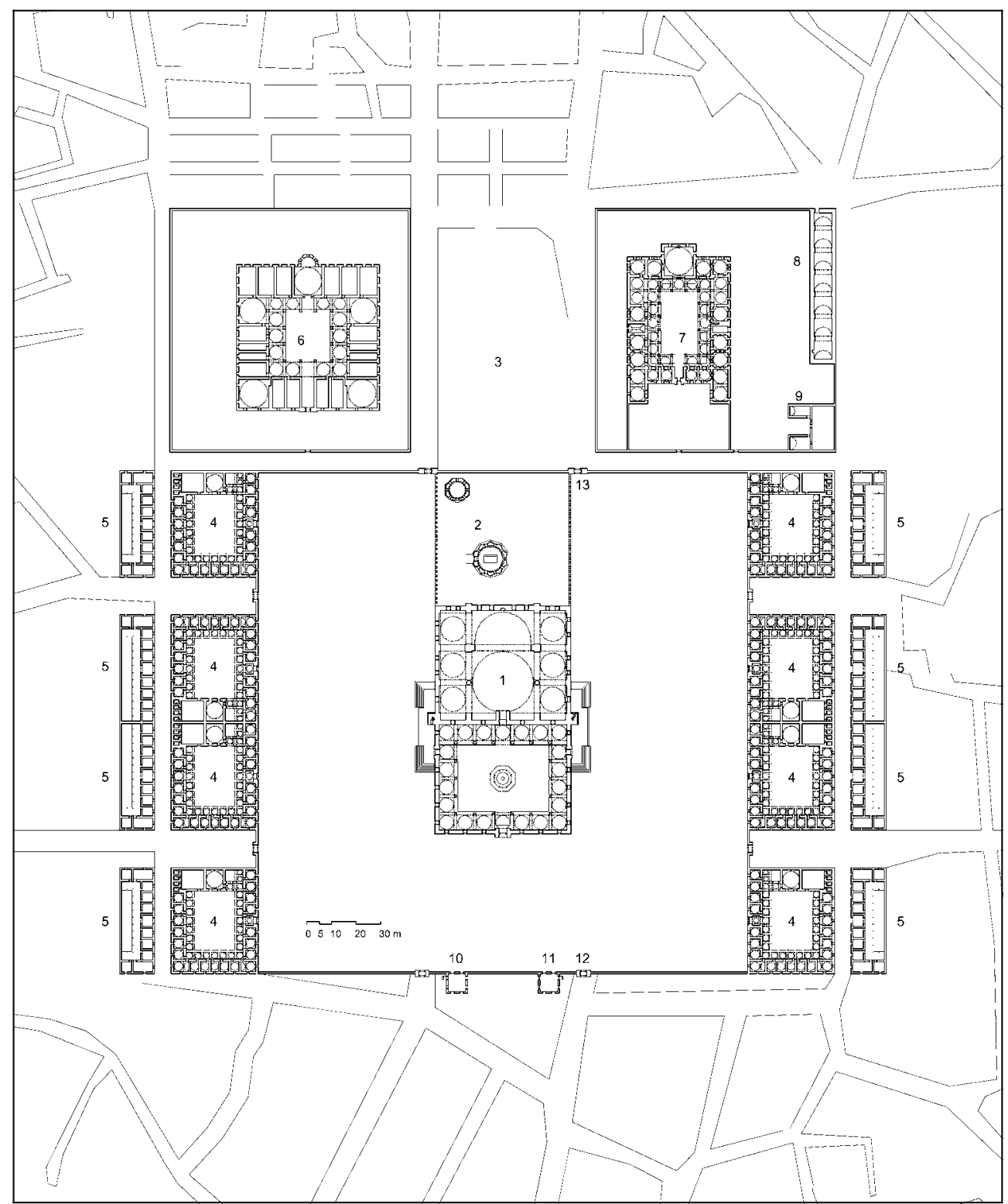

FIGURE 8.7 Istanbul, complex of Mehmed II, 867-875/1463-1470, plan (1. mosque; 2. mausolea; 3 . garden; 4 . madrasas; 5 . preparatory madrasas; 6 . hospital; 7 . hospice and soup kitchen; 8. stables; 9. kitchen; 10. elementary school; 11. library; 12., 13. gates.) PLAN FROM KAFESCIOĞLU, CONSTANTINOPOLIS/ISTANBUL 
tinction of the hospice-soup kitchen powerfully highlighted the continued, and augmented, symbolic import of this space (figure 8.8).

The foundation deed of the complex supports the view that Mehmed II's hospice and soup kitchen was in institutional terms, too, a first in Ottoman practice. Its expansive range of employees, separately recounted for the hospice ('imāret), the soup kitchen (mațbah al-imāret), and the stables, and its expansive kitchen expenses foresee the accommodation of a larger number of users (identified as students, dervishes-or the poor, fukarä-and travelers, according to the waqfiyya) compared to earlier royal or elite foundations. ${ }^{26}$ Mehmed II's soup kitchen and hospice compound created a new paradigm for royal imarrets of the following centuries, in Istanbul and beyond. ${ }^{27}$ Sited at a distance, the Kalenderhane, meant for those for whom the royal 'imäret did not seem to have space, is one of the two dervish lodges within the walled city that was part of Mehmed II's foundation. The building's name implies that it was allocated to antinomian dervishes rather than Sufis attached to a certain path. The waqfiyya, with its remarkably detailed stipulations regarding the dervishes and their shaykh's religious observances, their zikr performances, and Mathnaw $\bar{\iota}$ and poetry readings calls attention to the range of foreseen activities, and to the role of waqf in enforcing a particular order in the endowed establishment. $^{28}$

That Mehmed II succeeded in reordering the functions and meanings of the buildings of the royal complex may be evident in the narrative of the antinomian dervish Otman Baba's confrontations with figures of religious authority in Istanbul during the 870s/1470s. Otman Baba's Velāyetnāme portrays Mehmed II's mosque as a locus of the religious establishment. The ulama confronting the dervish for what to them were scandalous acts hailed from that mosque, which clearly was not a place to be frequented by the $b a b a$ who roamed the streets, squares, and marketplace of Istanbul, club in his hand and dervishes

26 Öz (ed.), Zwei Stiftsurkunden, Ergin, Fatih imareti vakfiyesi. Bidlīsī describes the 'imāret compound and the hierarchized configuration of the refectories serving the ulama, students, and the poor. He notes that the soup kitchen served nearly zooo people daily. Bidlisî, Heşt Behişt 76-77.

27 Baha Tanman (Sinan'ın mimarisi, 336-337) recognizes the prototypical role of Mehmed II's hospice-soup-kitchen-caravanserai compound for later Ottoman 'imārets. See also Singer, Imarets. Singer has tended to focus on 'imäret primarily as soup kitchen, and has been less attentive to the semantic and spatial shift that took place in the Ottoman notion of 'imäret in the later ninth/fifteenth century.

28 Öz, Zwei Stiftsurkunden; Ergin, Fatih imareti vakfiyesi; Kafescioğlu, Constantinopolis/Istanbul 99-103. 


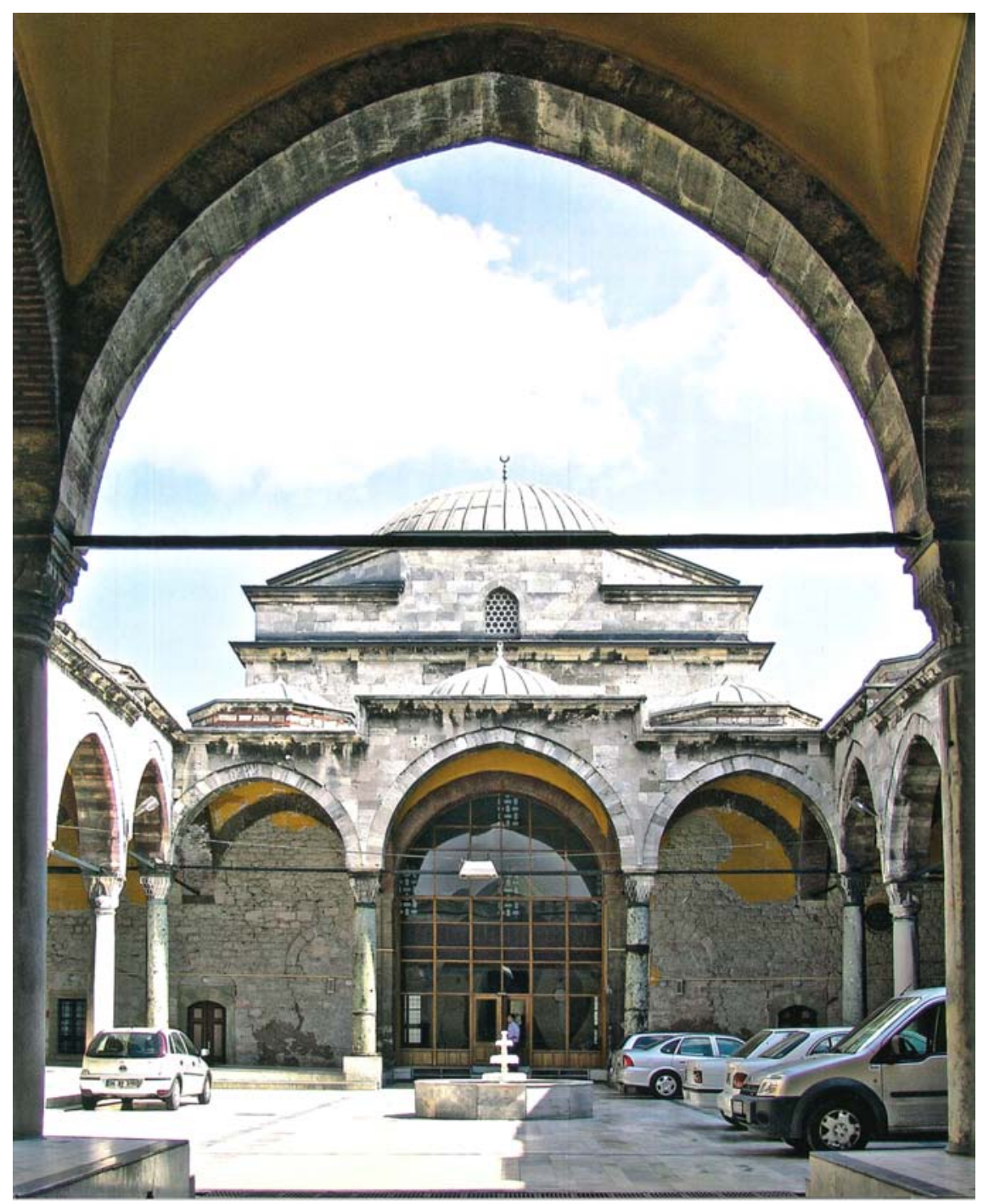

FIGURE 8.8 Istanbul, tābhāne and 'imāret (hospice and soup kitchen) of the Mehmed II complex, the courtyard PHOTOGRAPH FROM GÜNÜÇ, TÜRK KÜLTÜR VE MEDENIYET TARIHINDE FATIH KÜLLIYESI 
in tow. ${ }^{29}$ The confrontation between Sünbül Sinān (the shaykh of the Halveti lodge at the Koca Mușțafā Pasha Mosque and founder of the Sünbüliye branch of the Halvetis, d. 936/1529) and Șarı Gürz Hamza Efendi (the kadi of Istanbul, d. 928/1522) on the permissibility of devrān (rhythmic bodily movements in a circle during Sufi ritual), which took place some decades later in Mehmed II's mosque and was related in the Halveti shaykh Hulvì's Lemezāt (1621), too, powerfully highlights the mosque as a locus of orthodoxy as articulated by the Ottoman religious establishment. ${ }^{30}$

Two overlapping processes underlay the shift in patronage and architectural representation: the royal patron's changing relationship to the $g \bar{a} z \bar{\imath}$ and dervish milieu on one hand, and on the other, the processes of the Sunnitization of the Ottoman polity. Architecture and institutional patronage had their share in the long road to the final dissolution of the rapport between agents of the frontier and the all-powerful center; ${ }^{31}$ as they did in the dynamic, shifting, and longterm process of Ottoman Sunnitization. ${ }^{32}$

The abundance of masjid construction in the cities of Rum in the later eighth/fourteenth and ninth/fifteenth centuries may be brought into the picture, as an aspect of the latter process. Neighborhood masjids imposed a grid of Islamic urban markers in the developing cityscapes. Bursa, Edirne, and Istanbul are the best documented cities in this regard, thanks to a number of more complete surveys and studies. The less well-known Ayasuluk (Hagia Theodosius, Selçuk in modern Turkey), the Aydinid center through the eighth/fourteenth century and an intellectual node housing scholars hailing from Mamluk lands through the patronage of 'Īsā Bey, ${ }^{33}$ presents another striking case of seemingly methodical masjid construction dispersed throughout the urban area. ${ }^{34}$ A neighborhood masjid might be solely a marker of Muslim presence and pre-

29 Küçük Abdal, Velāyetnāme 111a-112a; Kafescioğlu, Constantinopolis/Istanbul 43, 235nı6. Ḥulvī, Lemezāt, cited in Öngören, Osmanlılar'da tasavvuf 374-376.

30 Cited in Öngören, Osmanlılar'da tasavvuf 374-376.

31 Kafadar, Between two worlds; Çıpa, The making of Selim.

32 See footnote 14.

33 Yıldız, From Cairo to Ayasuluk. On Aydinid literary patronage at large, see Ylldız, Aydinid court literature.

34 On masjid construction in ninth/fifteenth- and early tenth/sixteenth-century Istanbul, see Kafescioğlu, Constantinopolis/Istanbul 178-196. Ayverdi's surveys of early Ottoman architecture best capture the picture in Bursa and Edirne; Ayverdi, İlk Osmanll; and Ayverdi, Çelebi ve II. Sultan Murad Devri. Although Ayasuluk masjids present problems in identification and dating, they comprise a significant group from the later eighth/fourteenth and early ninth/fifteenth centuries. See Uğur, Selçuk (Ayasuluk) camive mescidleri; on late medieval Ayasuluk, see Foss, Ephesus. 
eminence (this, regardless of the religious identities of the area's residents ${ }^{35}$ ). Its widespread sponsorship was a product of compliance with Hanafi jurisdiction and formulations of the mosque as a semiofficial node vis-à-vis political authority.

The visible attention to masjid construction (by administrative, scholarly, or mercantile elites), which dispersed the spaces of daily prayer within the urban area, may also be considered in connection to a set of prescriptive texts underlining Muslims' obligation to perform the requisite prayers. Among them are Kuṭbe'd-dīn İzniḳ̂’s (d. 821/1418) Muḳaddime, ${ }^{36}$ sections of Devletoğlu Yūsuf Balıkesrīs Manzūm fikh (or Vikāaye tercümesi, 828/1424), ${ }^{37}$ and toward the end of the century, İsfendiyāroğlu İsmāīil Bey's Hulviyāt-ışăhī. ${ }^{38}$ Authored by the Çandaroğlu bey of Sinop (d. 884/1479), himself the builder of several mosques in his native Kastamonu-Sinop area and in Plovdiv, the city of his exiled governorship, the Hulviyāt-ışāhì includes lengthy sections of minute detail on every conceivable aspect of prayer. ${ }^{39}$ Commanding arithmetical precision in his knowledge of the rewards of canonical worship, İsmāîl Bey indicates that conducting the prayers at the masjid would bring twice the fazl than conducting them at home. ${ }^{40}$ İznikị’s long sections on the daily prayers include a recommendation on not leaving one's neighborhood masjid to go and pray at another mahalle only because the imam of the farther masjid seems to be more pious, suggesting that the socio-spatial integrity and stability of the urban neighborhood, and the religious authority's desire to control intra-urban mobility to achieve such stability, were concerns already in the early 800 s $/ 1400$ s. ${ }^{41}$ All three texts betray the authors' access to and compliance with Hanafi law in reference to legal denominations of the city (mıșr), the role of masjids and mosques vis-à-vis the definition of $m \iota s ̧ r$, and the legality of congregational prayer. Thus, they closely

Masjid construction, and denomination of neighborhoods through masjids, also in areas where large non-Muslim communities were resident in Istanbul, presents a good case for this. See Kafescioğlu, Constantinopolis/Istanbul; and Leal, The Balat district.

36 Kutbe'd-dîn İznikî, Mukaddime; and Krstić, Contested conversions 26-5o.

37 Aktan, Devletoğlu Yusuf'un Vikaye tercümesi; and Yıldız, A Hanafi law manual.

38 İsfendiyāroğlu İsmācīl Bey, Hulviyāt-ı şāhī.

39 On İsfendiyāroğlu's patronage of mosques, see Boykov, Anatolian emir in Rumelia. A copy of the Hulviyāt-ı şāhī was endowed by the chief architect Sinān to the masjid he founded in Istanbul, underlining the connection between earlier modes of Sunnitization and later tenth/sixteenth-century dynamics; Necipoğlu, The age of Sinan 15 o.

40 İsfendiyāroğlu, Hulviyāt-ı şāhī 286 r.

41 Kutbe'd-dîn İznikî, Mukaddime 205. The note is reflected in, and possibly adapted by, Ebū's-su'ūd Efendi in a fatwa on the impermissibility of praying in another neighborhood's Friday mosque, Necipoğlu, The age of Sinan 57. 
overlap with the notions and definitions of urban settlement Baber Johansen has traced in earlier medieval Hanafi legal texts. ${ }^{42}$

That there was an interconnection between the writings of such scholars as İzniḳi and İsfendiyāroğlu (himself a scholar and ruler) and the political authority's will to impose practices of normative religious observance is suggested by the creation, toward the end of Mehmed II's reign, of the figure of an official namāzcl, a person who was given authority to fine regular absentees from the five daily prayers and from the Friday congregational prayer. ${ }^{43}$ We see the namāzcı at work in one of the early court records of Üsküdar, dated 927/1521: here, the names of 28 individuals, one of them a janissary, are listed as those denizens of Üsküdar neighborhoods not attending daily prayers. ${ }^{44} \mathrm{~A}$ namāz sorucı (prayer inquirer) is present also in a Nasreddin Hodja story included in the Pertev Naili Boratav compilation, which provides a different perspective on the matter. This was the Hodja's answer to the question whether he performed his prayers: "Neither did I desire it, nor was it my lot." 45

Friday Congregation in the İmāret: Agency of the New Elite

Built within the walled city, and at spots that would soon develop into densely settled areas (unlike earlier 'imārets located at urban fringes), the 'imāretmosques founded by viziers in Istanbul were designed and instituted with attention to daily prayers. The early signs of the institutional and architectural change that turned the 'imāret into a mosque are fairly obscure, but nevertheless traceable. Murād II's Edirne 'imāret may present the first such building; while changes were introduced more systematically in later ninth/fifteenthcentury Istanbul. ${ }^{46}$ The early history of the foundation of Grand Vizier Mah-

42 Kutbe'd-dîn İznikî, Mukaddime 214-215; İsfendiyāroğlu, Hulviyāt-ı şāhī 242r-v; Aktan, Devletoğlu Yusuf'un, 213-216; Johansen, The all-embracing town 144-145, 148-152.

43 Terzioğlu, How to conceptualize 313-314; see also Necipoğlu, The age of Sinan, 48, for a 953/1546 reference to the tyranny of the namāzcı figure, which rendered the practice unfavorable. See also the article by H. Evren Sünnetçioğlu in this volume.

44 Yılmaz (ed.), İstanbul kadı sicilleri, Üsküdar i, 434: "Bu taf̣̦il mahallelerde olan bī-namāzı beyān eder ki zikr olunur." There are a number of such registers in the court register archives; this is the earliest I have encountered.

45 "Ne heves etdüm, ve ne ol da bana nasib oldı," Boratav, Nasreddin Hoca 184, no. 338; also in Duman, Nasreddin Hoca 325, who gives the source as Hikāyet-i Hoca Nașreddīn, Bibliothèque nationale de France, MS S.T. 1395, dated 1207/1792, 45r.

46 Ayverdi, Çelebi ve II. Sultan Murad Devri 405-415. My thanks to Gülru Necipoğlu for drawing my attention to the features of the Edirne Muradiye that depart from zāviye/'imāret design. For evidence regarding interventions to the building, see footnote $5^{8}$. 
mūd Pasha, "absolute deputy" of Mehmed II, a primary agent of Ottoman expansion, imperialization, and courtly and urban patronage for two decades before his summary execution in $878 / 1474$, records the shift taking place. ${ }^{47}$ Contemporary accounts of Mahmūd Pasha's foundation dating to the $86 \mathrm{os} / 146 \mathrm{os}$ and 87os/147os identify the building as 'imāret and hānkāh ; authors highlight the founder's generosity, the feasts that were offered there, and the presence of travelers who were recipients of the vizier's generosity. Mu'alli's lengthy praise of Maḥmūd's charity, generosity, and pious foundations in his Hünkārnāme (ca. 88o/1475) links the foundation of the hānkāh to the feasts offered by its patron. ${ }^{48}$ The foundation inscription identifies the building as a house of charity (dāra hayren).$^{49}$ Enverī, who dedicated his Düstūrnāme to the grand vizier in 869/1465 makes no mention of a mosque in Istanbul among Mahmūd Pasha's foundations. Rather, he praises the 'imarret (and within the same passages, also hānkāah), and like Mu'ālī some years later, the feasts offered to scholars and men of religion. ${ }^{50}$ The ambiguity as to the early history of the building, and its multiple identifications is extended also to the visual record. Two city views from the early 148os feature the building: the Vavassore view depicts it without a minaret and labels it moscha; in the view in a Buondelmonti manuscript the building is depicted with a minaret and is labeled imarat. ${ }^{51}$ Extant inscriptions of Mahmūd Pasha's 'imāret and its contemporaries (unlike that of Mehmed's New Mosque) do not refer to them as mosques: Maḥmūd Pasha's and Hāṣ Murād

47 On Mahmūd Pasha, and his urban and cultural patronage at large, see Stavrides, The sultan of viziers. The T-type structure constructed as part of the commemorative complex at the discovered grave of Ayyūb al-Ansārī in extramural Istanbul, also in 1459, was also likely an 'imāret at the time of its foundation. For the Mahmūd Pasha 'imāret and mosque, see Ayverdi, Fatih devri iii, 433-451; Kuran, The mosque; Emir, Erken Osmanlı 19o-191; Kafescioğlu, Constantinopolis/Istanbul 109-119. In Constantinopolis/Istanbul I argued that the building was founded as a mosque. Having reviewed the evidence, I propose a revision of that argument here.

48 Mucāī, Hunkārnāme 8b-1ob; for a transcription of the text, see Balata, Hunkarnāma.

49 By contrast, Meḥmed II's mosque is denoted as cāmic in its foundation inscription. In Maḥmūd Pasha's foundation, the inscriptions on the side entrances to the hospice rooms, and the hadith and Quranic quotation both evoking a masjid, must have been put in place alongside the restoration inscription, documenting the Osmān III restoration. For the texts, see http://www.ottomaninscriptions.com/information.. aspx?ref=list\&bid=426\&hid $=2687$ [accessed 26 July 2020].

50 Enverī, Düstūrnāme 71-72.

$5^{1} \quad$ For the maps, issues of their dating, and the identification of sites they represent, see Kafescioğlu, Constantinopolis/Istanbul 143-161. It is not quite certain exactly which site is labeled by Vavassore, but its location certainly points to Maḥmūd's building. It has no minaret. It should be noted, though, that the only minarets depicted in this image are those of Mehmed II's mosque. 
Pasha's (d. 882/1477) inscriptions carry the phrase dāra hayren, Rūm Meḥmed's (also depicted with a minaret by the maker of the Buondelmonti view), dār alrafi.52

Architectural evidence suggests that the Mahmūd Pasha imāret may have gone through an intervention that remade it into a mosque. Based on his careful architectural survey of the building, Sedat Emir has argued that the minaret of the Mahmūd Pasha 'imāret was a later addition and not part of the original building; the current restoration work that has revealed structural details of this section of the building has corroborated this view. ${ }^{53}$ That it was not a much later addition is suggested by its presence in the Istanbul view in the Buondelmonti manuscript mentioned above. Completed in 912/1507, Idrīs-i Bidlisis's Hasht Behesht leaves no doubt that Mahmūd's foundation functioned as a congregational mosque at that time. Not only does he refer to the mosque alongside the hānkāh, ribāt, and madrasa (and writes on the expansive charities, generosity, and hospitality of Mahmūd and his patronage of poets and scholars), but he also gives an account of the expenses of the foundation, which included the allowances for a hațīb, or deliverer of the Friday sermon. ${ }^{54}$

In view of the absence of any references to the congregational mosque by Mahmūd Pasha's contemporaries, the addition of the minaret at an uncertain date (a theme that will come up again in the following section of this paper), and in view of documents and narratives from the following decades that refer to it as cāmi'-işerîf, I suggest that the building, founded as an 'imāret, may have

$5^{2}$ Üsküdar court records up to the mid-940s/1540s have numerous references to the Rūm Mehmed Pasha 'imāret. By 953/1546, and in later dealings of the sharia court with the same foundation, the reference is always to the Mehmed Pasha Mosque.

53 Emir demonstrated that within the northwestern corner room, 30 to 35 centimeters had been scraped off from the western corner of the wall separating the portico from the interior, from the ground level up, the scraped part ending in a console at the point it reaches the top of the minaret door on the western wall. He argued that this was done in order to allow for the opening of an entrance to the minaret, and he took this as evidence that the minaret was a later addition; Emir, Erken Osmanl 216-217, photographs 582, 583 . As the building has been closed for restoration, I have not been able to conduct an on-site examination. Baha Tanman, the adviser for the current restoration project (disrupted due to the Covid-19 pandemic) has corroborated that the structural details of the minaret's connection to the main building suggests a later intervention; personal communication, 22 April 2020.

54 A wage of 25 akçes for the $h a t ̦ i ̄ b$ and 15 for the imam are recorded by Bidlīsī, who also notes that the daily expenses of the Mahmūd Pasha 'imāret was close to 1,ooo aķ̧̧es, Heşt Behişt 91. The original waqfiyya of the Mahmūd Pasha foundation has not surfaced. The waqfiyya summary recorded in 1546 has the date as $878 / 1474$, the year the vizier was executed. The summary records a 15 akçe wage for the hațïb; Barkan and Ayverdi, İstanbul vakıfları 4245 . 
been converted into a congregational mosque with additions to and alterations of its waqf. Two possible dates for this intervention would be the completion of Mehmed II's mosque in 1470 and Mahmūd Pasha's execution in 878/1474, after which his expansive endowment was confiscated into the royal treasury. ${ }^{55}$ If, on the other hand, the main building of Mahmūd Pasha's foundation was from the start instituted as a congregational mosque-and-hospice, housing the Friday prayer and sermon as well as accommodative functions, the narrative sources discussed earlier suggest that this novel arrangement was lost on the grand vizier's contemporaries.

The spatial configuration of buildings founded by Mahmūd Pasha and his contemporaries in the upper echelons of Ottoman rule in Istanbul and beyond present a search for a middle ground that would bespeak the emphasis on congregational prayer and, at the same time, highlight the builders' charity through offerings of hospitality. ${ }^{56}$ The hospice rooms of Mahmūd's and other viziers' buildings in Istanbul were clearly used for purposes of accommodation and socializing, as their fireplaces (or traces thereof) and their storage niches indicate. Rather than isolating the provision of accommodation and food to areas beyond courtyards and walls as in the royal complex, the architects intervened in the spatial configuration and circulation patterns within the established conventions of zāviye/ imāret design. Hence, the Mahmūd Pasha mosque, with its corridor separating the hospice rooms from its main prayer space, a design that may have been inspired by late Byzantine church building in Constantinople. ${ }^{57}$ The central domed hall of the building, in earlier imärets a central space giving way to the prayer eyvān and to guest rooms, was now part of a larger prayer space along the entrance axis. ${ }^{58}$ Unlike earlier T-type

55 The Mahmūd Pasha waqf was to be partly restored during the reign of Bāyezīd II. The changes in the Mahmūd Pasha foundation following his execution, and during the reign of Bāyezīd II, are discussed in Kafescioğlu, Constantinopolis/Istanbul 117-118, 247n185, and 248nı86; and in greater detail in Kafescioğlu, The Ottoman capital, 180-182.

$5^{6}$ For discussions of the architectural and spatial shift in late ninth/fifteenth-century T-plan buildings, see Kuran, Early Ottoman; on hospice functions of T-plan convent-mosques, see Necipoğlu, The age of Sinan 94-95; Kafescioğlu, The Ottoman capital 165-169, 194196; Kafescioğlu, Constantinopolis 110-114, 131-132. Sussan Babaie's discussion of notions of conviviality as articulated by the ruling body in the Safavid context may offer perspectives on the uses of royal and elite 'imärets and mosque-and-hospice buildings in the early Ottoman cultural milieu, see Babaie, Isfahan 1-30.

57 The layout with a corridor separating the main prayer hall from hospice rooms, and its possible connection to late Byzantine church construction in Constantinople, is discussed in greater detail in Kafescioğlu, Constantinopolis/Istanbul 112-114.

58 The Edirne 'imāret of Murād II, with a waqfiyya dated 830/1426-1427, appears at first sight to be an earlier example of such a configuration, as the prayer eyvān here has the 
buildings where the central hall was covered with a more prominent dome with an oculus, here the two successive domes covering the prayer hall were of equal size and height. Separate side entrances to the hospice rooms, a new feature of T-type buildings of these decades, ensured that the users of the hospice rooms (ayende u revende) did not intervene with the prayer space, which would be entered through the arcaded portico and the principal portal. Such side entrances would be opened in many earlier 'imāret buildings as they were converted into mosques, a topic the final section of this paper will turn to.

The particular spatial and volumetric composition that shaped the exterior configuration of the urban 'imāret, a hallmark of the T-plan building as a "type," must have had a role in its continued use. This easily recognizable composition rendered the building with its multiple functions and accommodative spaces immediately recognizable. ${ }^{59}$ The visual configuration of the early 'imārets, easily identifiable signposts of sultans' and emirs' hospitality, and centerpieces of expansive foundations that connected the cities to the hinterland where founders were patrons of entrenched networks of property and production, lived on in the imäret-and-mosque of the later ninth/fifteenth century. ${ }^{60}$

same elevation as the central hall. However, Aptullah Kuran has noted that excavations revealed the original floor of the central hall, which was at a lower level than the eyvāns. The accounting book of its foundation, from 1488 and 1489 , has expenses for a hațīb, pointing to its use as a congregational mosque at that time. The Edirne historian 'Abdu'rrạ̣mān Hibrī notes that it was founded as a Mevlevi lodge, and was later converted into a mosque; this is corroborated by Evliyā Çelebi, who attributes the conversion to the founder, Murād II. Evliyā's mention of Murād II replacing the wooden floor of the ceremonial hall with marble during the conversion, too, may explain the unusual contiguous space under the mihrab dome and the central dome. Evliyâ Çelebi seyahatnâmesi iii, 228. As noted separately by Kuran and Emir, the side rooms were most likely converted into eyvāns later, by opening arches into the partition walls between the central space and the rooms. Kuran observed the narrowness of the arches giving way to the side spaces; Emir observed that the original doors opening to the side rooms remain but have been converted into closets. It may be fruitful to consider the possibility of two different interventions to the building. For a survey of the building and relevant documents, see Ayverdi, Çelebive II. Sultan Murad 405-415. For arguments regarding interventions to its fabric during its conversion into a mosque and observations regarding the hospice rooms, see Kuran, The mosque 124-125, 132; Emir, Erken Osmanlı 212-213, photographs 561-564.

59 The 'imārets of Murād I, Bāyezīd I and Mehmed I in Bursa diverge from the predominant volumetric composition and side facade arrangement of majority of T-type buildings: their original layouts feature three eyvanns, with two at the sides, between the hospice rooms. The hospice rooms are not pronounced in the exterior volumetric configuration, rather they are rendered part of the prismatic mass of the main building. However, the domical arrangement and protruding mihrab eyvān are recognizable exterior features of the type. See also footnote 100 .

6o Kayhan, 16. ve 17. yüzyllarda; York, Imarets, Islamization. 


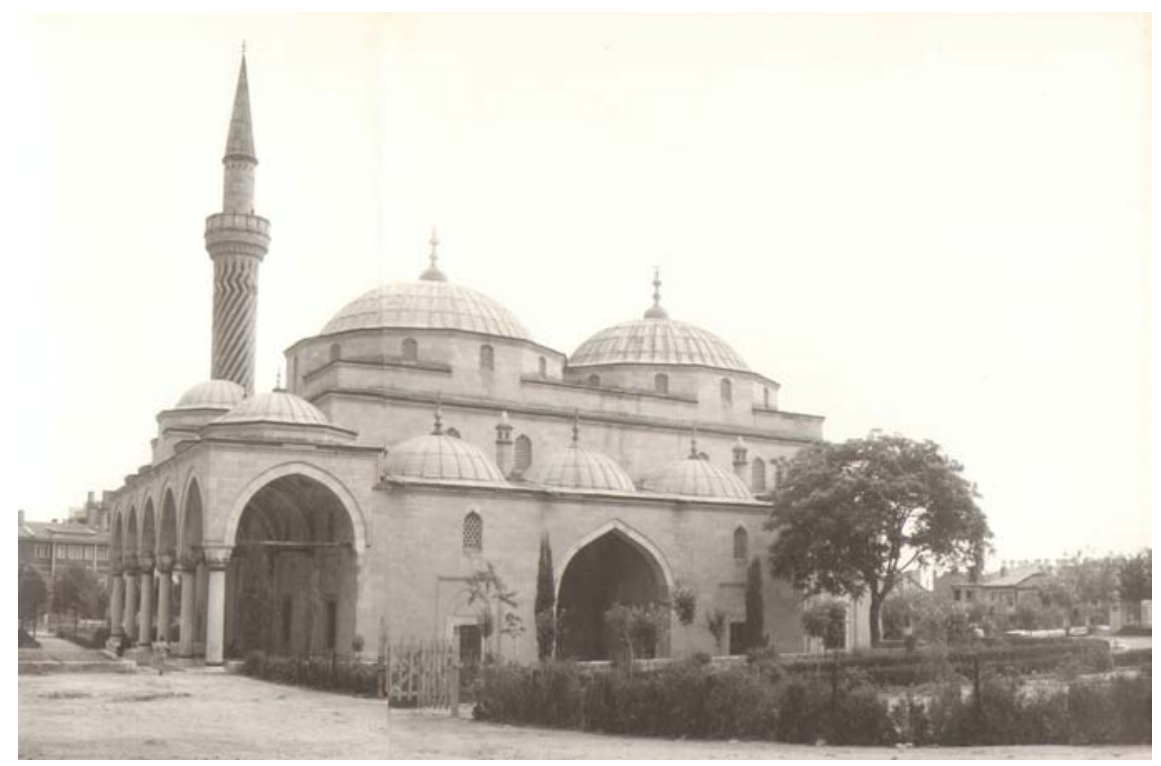

FIGURE 8.9 Afyon Karahisar, 'imāret and mosque of Gedik Aḥmed Pasha, 879/1474, exterior view from south

BY PERMISSION OF THE BOĞAZIÇI UNIVERSITY APTULLAH KURAN ARCHIVE

None of the original waqfiyyas of the elite foundations in Istanbul have surfaced. The Afyon foundation of Gedik Ahmed Pasha, whose waqfiyya copy carries the date $879 / 1475$, and indicates the completion date of the same year, captures the architectural and institutional shift that I hope to highlight in this paper with more clarity (figures 8.9 and 8.10). ${ }^{61}$ Completed within the same years as two other viziers' foundations in Istanbul and Üsküdar (those of the pashas Hāṣ Murād and Rūm Meḥmed), the Afyon building presents an elaborate response to the new use as congregational mosque that the longestablished type was now put to. As in the Istanbul buildings of Mahmūd Pasha and Hās Murād Pasha, the two successive domed units beyond the entrance constituted the prayer space and were not differentiated by their height or by the elevation of the mihrab eyvān. Its side eyvāns, centering the lateral facades and providing entry into the hospice rooms, freed the main space of the mosque from circulation between its main entrance and the hospice rooms. Solving a use and circulation problem presented by the use of the Tplan for a congregational mosque, this new layout at the same time imparted a monumental aspect to the hospice sections. The rooms centered by arched

61 Vakıflar Genel Müdürlüğü Arşivi, 2088. 


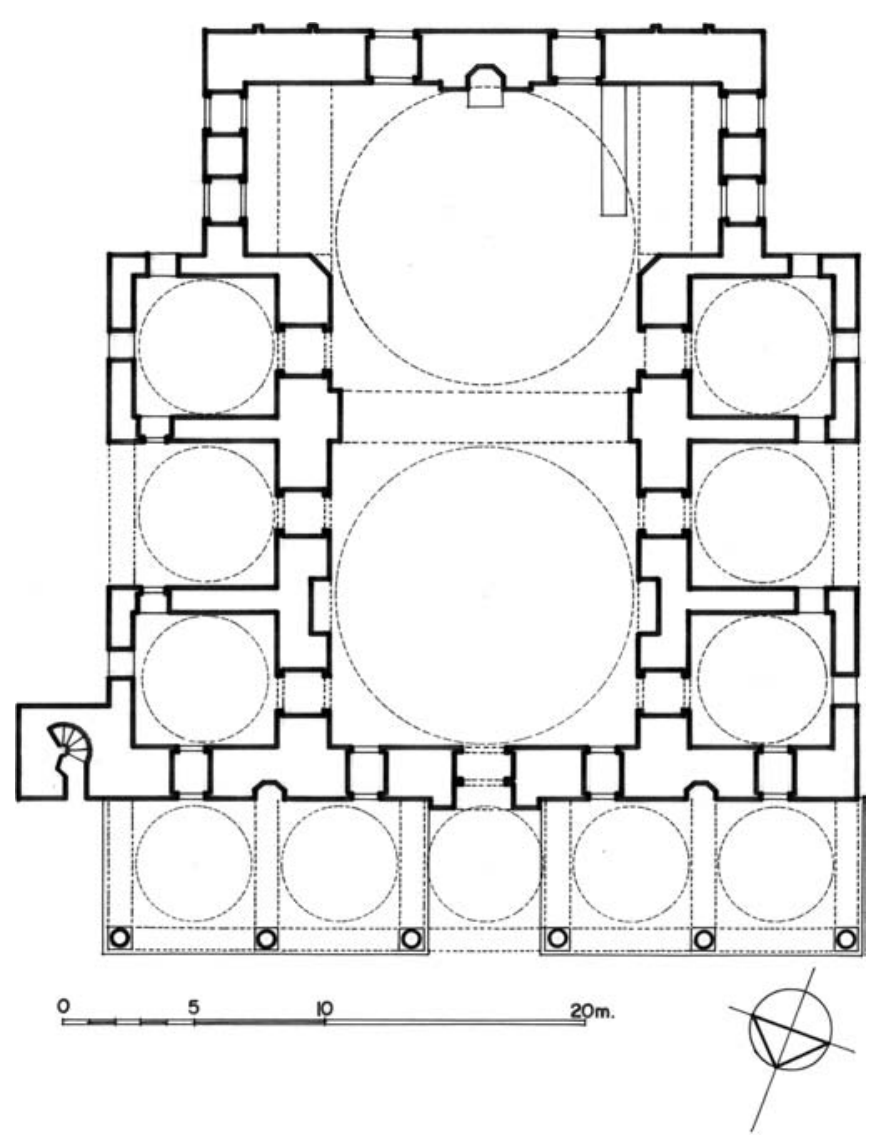

FIGURE 8.10 Afyon Karahisar, 'imāret and mosque of Gedik Ahmed Pasha, 879/1474, plan BY PERMISSION OF THE BOĞAZIÇI UNIVERSITY APTULLAH KURAN ARCHIVE

eyvāns claim an equal status for the hospice with respect to the porticoed main entrance of the building. The Afyon building's side facades in fact bear a semblance to the layout and entrance façade of the 'imāret of Gāzī Evrenos in Komotini, which features a monumental eyvān (with no prayer space opening onto it) and two side rooms; a resemblance that may not be accidental. ${ }^{62}$ One could read this as a duality in the Afyon building's visual language - the side eyvāns flanked by hospice rooms associated with a former architectural lan-

62 On the architecture of Evrenos 'imāret in Komotini (completed before 785/1383), see Kiel, The oldest Ottoman monuments; Çağaptay, The road from Bithynia. 
guage of $g \bar{a} z \bar{\imath}$ patronage and prestige, and the arcaded portico of the entrance façade, featuring an aesthetic articulated in royal buildings of Bursa, Edirne, and Istanbul, bespeaking a connection to the political center.

Gedik Ahmed Pasha's endowment for a congregational mosque-and-'imāret is repeatedly referred to as cāmici $i$ şerîf (or, mescid-i cāmic) ve imāret in the $879 / 1475$ waqfiyya. The building and the waqfiyya present a short-lived duality in the appointments of an 'imäret's leading personnel: a shaykh for the 'imāreti cāmi' is appointed, while the well supplied and staffed soup kitchen ('imāret in the document), has its own shaykh; both men were expected to be modest, noncovetous, and abstinent. The mosque-hospice, with a hațib and a shaykh, the latter a subordinate to the former, captures the transformation of the institution well. The document stipulates a ten dirhem wage for a hațīb (who should be a scholar knowledgeable in Arabic and in control of his speech), an imam with the same wage and knowledgeable in conducting daily prayers, and two muezzins. Allowances for 15 Quran readers and ten tehlïlhān (chanting the profession of God's unity), who would read for the founder's soul following each of the five daily prayers, suggest an intense atmosphere of devotional reading and chanting in the mosque. ${ }^{63}$ The building's local name, "imäret cami"," too, in place at least since Evliyā passed through Karahisar, points to the same configuration of expanded use, as congregational mosque, as hospice, possibly also as dining hall of the soup kitchen. Gedik Ahmed's foundation deed suggests that the earliest documents of imarret-mosques founded in Istanbul in the 870 os/1470s, preserved in the waqf survey of 953/1546, may reflect the allotments of the time of their composition. If Mahmūd Pasha's 'imāret had in fact been converted into a congregational mosque subsequent to its construction, this may have taken place during these years. This was also when the viziers Hāṣ Murād and Rūm Meḥmed created their foundations, in Aksaray within the walled city of Istanbul and in Üsküdar across the Bosphorus.

The viziers' constructions endowed intramural Istanbul with multiple Friday mosques. This was not a novelty either in the larger Islamic world or in the Ottoman domains. ${ }^{64}$ As far as Ottoman practice was concerned, the sponsorship of multiple Friday mosques in a town had been more of a representational affair (rather than one of implementing and hosting multiple congregational communities within a town), as implied by Edirne's Eski and Üç Şerefeli

63 Oil and mats for the mosque were provided for, as were allowances for a leather worker employed in the mosque and the 'imāret, a doorkeeper, two sweepers for the 'imāret and the stables, four bakers and their assistants, four cooks and their helpers, a dishwasher, a wheat grinder, a repairer of buildings, and four revenue collectors.

64 Johansen, The all-embracing town; Grabar, The architecture of the Middle Eastern city. 
mosques, both at the city center and the latter built a stone's throw from the former. As much as the new mosque construction in Istanbul during the early decades under Ottoman rule answered the need to remake the city's image through Muslim monuments, they also present something of a blueprint of the Hanafi classification and hierarchy of mosques. Friday mosques and neighborhood masjids created the physical nodes for multiple congregations and a quasi-parochial organization, foreseen and imposed (if sometimes only as far as state authority and bureaucracy were concerned) on the urban area. ${ }^{65}$ Hanafi law and Ottoman practice continued to hold that the construction of a Friday mosque was to be ordained by sultanic authority; in earlier Ottoman practice this was a sultan's prerogative. ${ }^{66}$ Mosque-hospices founded by the new elite in Istanbul, Gedik Aḥmed's Afyon foundation, alongside Maḥmūd Pasha's Sofia mosque, a multidomed hall modeled after Bursa's Ulu Cami and Edirne's Eski Cami, expanded what was until then the royal prerogative of founding Friday mosques to subroyal builders. ${ }^{67}$

The change in the architecture and the institutional framework of the 'imāret was brought on by agents of the newly consolidated center, as revealed by a look at 'imārets other patrons built in other places. The 'Īsā Bey 'imāret in Skopje, contemporaneous with the Afyon building, and two mosque-hospices built by viziers in Istanbul is a case in point. The founder was a descendant of Paşa Yiğit and therefore a member of a well-entrenched, powerful, and wealthy frontier dynasty, himself a frontier lord and an agent of Mehmed II's military exploits in the Balkans. He was also the founder of infrastructure and charities that directed income from his expansive possessions into projects in Skopje, Sarajevo (where his palace gave its name to the city), and elsewhere in Bosnia. 'Īsā Bey's Skopje building, which is identified as a hānkāh in its 874/1469 waqfiyya and as 'imāret in its inscription dated 880/1475-1476, ${ }^{68}$ presents a conventional interpretation of the T-type building: it features a central hall followed by a prayer eyvān on the entrance axis, both domed, and hospice rooms to the

65 Johansen, The all-embracing. That this matrix was imposed on Istanbul has been discussed in Kafescioğlu, Constantinopolis/Istanbul 180-184.

66 'Īsā Bey's Sarajevo Friday mosque was built in 862/1458 and was dedicated to Meḥmed II: Kemūrāzāde Seyfeddīn, Sarāybosnada ebniyye-i hayriyyenin, 3; Pelidija and Emecen, Îsâ Bey. On the construction of Friday mosques through sultanic consent, see Necipoğlu, The age of Sinan $47-48$.

67 See also Hartmuth, A late ninth/fifteenth-century change, which locates the establishment of plural congregational mosques in Balkan cities, and by subroyal patrons, in the reign of Bāyezīd II.

68 The waqfiyya is dated $874 \mathrm{AH}$ and indicates the foundation date as $871 \mathrm{AH}$; Ayverdi, Fatih devri iv, 868. 
sides. ${ }^{69}$ The foundation deed entrusts the operation of the hospice to an ahi (unlike the majority of foundation deeds that have been preserved, which have allowances for a shaykh) implying a direct connection to the artisanal community of the city and patronage extended to its members. ${ }^{70}$

Where the institutional patronage by frontier lords and the old elite of the Ottoman domains is concerned, 'Īsā Bey's Skopje foundation is not exceptional. Imārets founded during the reign of Mehmed II by patrons of different background and standing, who were not part of the new slave $(k \bar{u} l)$ elite, all follow earlier spatial and institutional configurations: they are foundations whose primary aim was providing food and shelter to a range of users. ${ }^{71}$ While the greatest expenses within their endowments are directed toward the distribution of food, their endowment deeds also highlight their functions as places for daily prayers, and allowances were set aside for prayers and Quran readings for the soul of the founder. The functions of the 'imaret as registered in İshāḳ Pasha's Inegöl building, founded in his town of origin in 873/1468, captures this well: the imāret with its rooms, courtyard (muhavvața), kitchen, storage places, stables and other dependencies was intended as a residence and a place for dervishes ( fukarā and mesākin), a halting place and a refuge for those who came and went, and for Muslims whether they were traveling or resident. The introductory passages of the waqfyya, on the other hand, contain the hadith "Whoever builds a masjid for God, God will build for him a house like it in paradise." ${ }^{72}$ This emphasis on the masjid in an 'imäret's waqfyya may be novel: it is not present, for example, in the introduction sections of Murād I's and Bāyezīd I's endowment deeds of their Bursa foundations, dated $787 / 1385$ and $802 / 1399-1400$ respectively. ${ }^{73}$ It has been noted that a third of the imarrets built up to the early decades of the ninth/fifteenth century did not originally feature a mihrab, ${ }^{74}$ also an indication that the function of the elevated

69 On this building in the context of İsḥāḳ Bey's and 'Īsā Bey's architectural patronage in Skopje, see Hartmuth, Building the Ottoman city.

70 'Isā Beg's Sarajevo foundation of $866 / 1462$, too, is for a zāviye directed to the use of students, Sufis, gāzis and seyyids, alongside a public bath and a bridge over the river Miljacka; Ayverdi, Fatih devri iv, 847 .

71 Such as those of Hamza Bey in Bursa, Hiżır Pasha in Amasya, Çandarlı İbrahīm Pasha in Edirne (858/1454), Sinān b. Elvān in Geyve, Ayverdi, Fatih Devri iii, 27-3o, 89-98, 209-210, 275-277.

72 Tamer, İshak Pasa Vakıfları, waqfiyya facsimile.

73 For the endowment deed of Murād I see, Gökbilgin, Murad I. This is the facsimile of the $802 / 1400$ waqfiyya, which is a copy of an earlier foundation deed dated $787 / 1385$. For the foundation deed of Bāyezīd I, see Ayverdi, Yıldırım Bayezid'in Bursa vakfiyesi.

Emir, Erken Osmanlı mimarlığında 231-232. 
eyvān on the entrance axis as a masjid, in those buildings that did have a qibla orientation, came to be accentuated through the course of the ninth/fifteenth century.

\section{3}

\section{Spatial Rearrangements and a Broader Range of Builders}

Some two decades after founding the Inegöl building, in 896/149o-1491, İshāk Pasha founded another imāret in Salonica. It was similar in most details of its allocations, with the exception that this imāret had allowances for a Friday preacher, and hence, like Gedik Ahmed's Afyon building, was to function also as Friday mosque. ${ }^{75} \mathrm{~A}$ few years earlier (in 891/1486) the city of Amasya had become home to an imäret founded and constructed as a hospice and Friday mosque. The foundation of Mehmed Pasha, member of the powerful Amasya family of Yörgüç Pasha, features a single dome flanked by hospice rooms in an arrangement akin to the reverse-T. However, it attaches sets of two hospice rooms aligned with the entrance to the two sides of a single domed mosque, whereby the rooms could be accessed from the mosque as well as via the entrance arcade of the building. ${ }^{76}$ Founded in the princely capital that had been a site where the Halvetiye was established in the lands of Rum, Mehmed Pasha's lodge was founded specifically for Halveti dervishes. ${ }^{77}$

İshāạ Pasha's Salonica foundation, and that of Meḥmed Pasha in Amasya, take us into the 89os/148os, when a new configuration of the 'imäret space was set in stone first in Istanbul. The Grand Vizier Dāvud Pasha's foundation $(890 / 1485)$ is a single domed mosque with hospice rooms to the sides, with separate entrances that are reminiscent of the side portal arrangements of Gedik Ahmed's Afyon 'imāret-mosque. With rooms now attached to a unitary prayer space, it bespeaks the continued importance of the ideals of hospitality.

In the aftermath of the partial reconciliation with agents of the earlier order, following Mehmed II's demise (which involved the restoration of some of the endowments and freehold property appropriated by Mehmed II, the welcoming to the capital city of Sunni-oriented Sufi groups, among them Halvetis

75 The building continued to be denoted as 'imāret, unlike most others from this period. Evliyā described it as Alaca 'İmāret Cāmi', Evliyâ, Seyahatnâme viii, 66.

76 Like Gedik Ahmed Pasha's foundation in Afyon, this is one of the few 'imārets of the period where an original minbar is preserved, bearing witness to the institutional status of the building as Friday mosque and lodge. Yüksel, II. Bayezid 39-43.

On Amasya lodges and the Halvetiye, see Karataş, The city as historical actor. 
of Amasya and Naqshbandis in particular), Bāyezīd II (r. 886-918/1481-1512) and his architects revisited the middle ground formulated by the designers of late ninth/fifteenth-century 'imarret-and-mosque buildings. These included Gedik Ahmed and, later, Dāvud Pasha foundations that had sought to combine Friday mosque and 'imāret under the same roof, and to keep them separate from each other. Three royal buildings founded by Bāyezīd II and Süleymān I between the 1480 os and 1520s, which departed from Mehmed II's innovation in mosque design, call attention to the dialogue and reciprocity between nonroyal and royal foundations. Hence, the layout of prayer hall and guest rooms with separate entrances attached to it that gave shape to Bāyezīd II's mosques in Edirne (889-893/1484-1487) and Istanbul (906-911/1501-1505) and, later, to the commemorative mosque built by Süleymān for Selìm I (929/1522). To the single-domed mosques of Bāyezīd in Edirne and Selīm in Istanbul, and to the Hagia Sophia-inspired design of Bāyezìd's mosque in Istanbul were added hospice sections that were laid out in a novel, palatial design. They feature four-eyvān cross-axial arrangements with central, lanterned domes that transpose the central halls of early imärets into this separate hospice space attached to the mosque, giving way to four rooms at the corners. The layouts of these hospice sections carry reminiscences of the royal imärets of Bursa with their cross-axial arrangements and multiple eyvāns, suggesting that they carry deliberate references to these earlier structures. ${ }^{78}$ Visiting these buildings in the later tenth/sixteenth century, the geographer and traveler 'Āşık Meḥmed described the Bāyezīd hospice as a dārǚż-żiyāfe (banquet hall) composed of connected rooms. He separately mentioned the kitchen (mațah-ı ta'äm) and refectory (me'kel-ița'äm) for the poor and the needy from among Muslim men and women. He thereby suggested a difference of status between those guests who ate and were offered hospitality at the mosque's $d \bar{a} r \ddot{u} \dot{z} \dot{z} \dot{z} \dot{y} y \bar{a} f e^{79}$ and those offered food and lodging in the soup kitchen, hospice, and caravanserai complex beyond the outer enclosure of the mosque. Describing Selīm I's mosque, 'Āşı Meḥmed recounted the same units again: a dārǘż-żiyāfe that adjoined the mosque for travelers (misāfirin) and a kitchen and refectory for the poor and the poor among the madrasa's students (figure 8.11).

78 See footnotes 59 and 100.

79 'Āşlk Mehmed twice mentions the dārǚż-żiyāfe for travelers (misāfirīn) and indicates that the refectory $(m e ' k e l)$ was for the poor students and for the poor and the needy Muslims: fukarā-yı țalebe-yi 'utūm; fukarā ve zu'afā-yi muslimīn ve muslimāt; Aşık Mehmed, Menâzirül'-avâlim 1089-109o. 


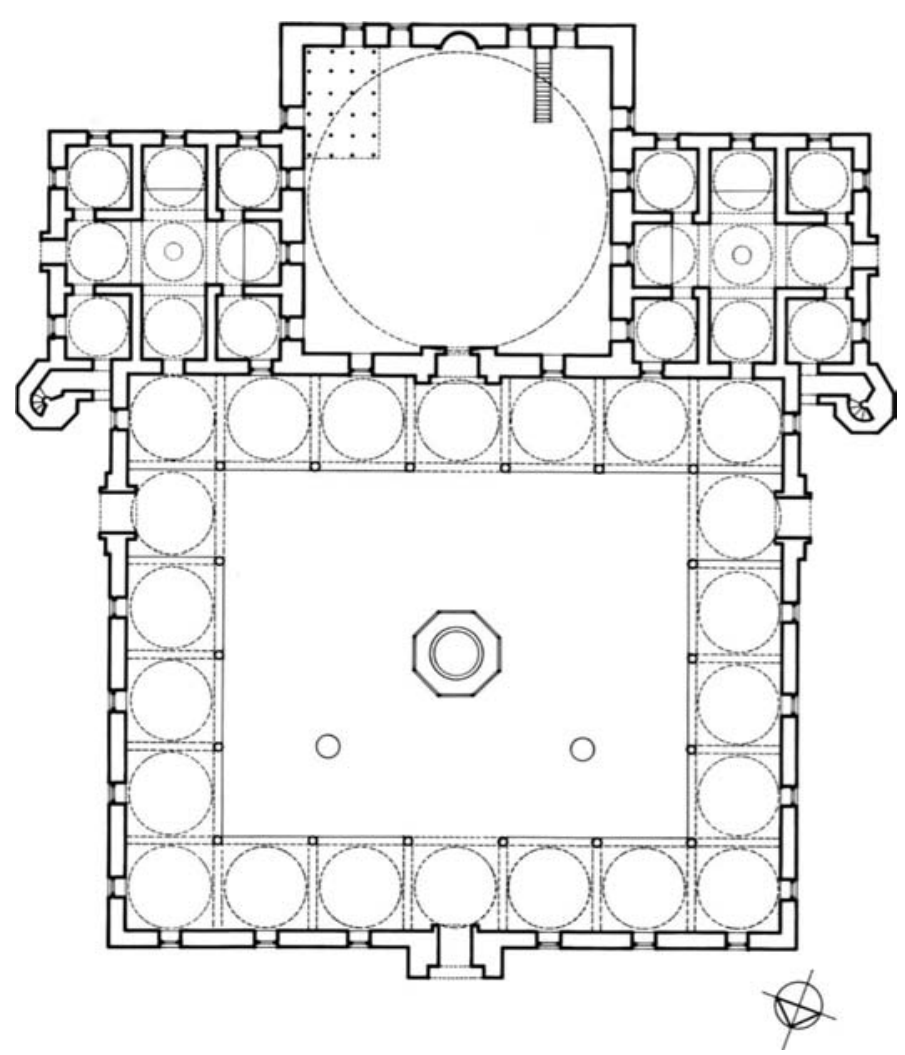

FIGURE 8.11A Edirne, mosque and 'imāret of Bāyezīd II, 893/1487-1488; plan BY PERMISSION OF THE BOĞAZIÇI UNIVERSITY APTULLAH KURAN ARCHIVE

During these decades, when former codes of hospitality and former connections between spaces of religious observance and spaces of accommodation were being redefined, the patronage profile of the structures that housed dervishes and "those who came and went" also shifted. Bāyezīd II and Süleymān were patrons of several Sufi lodges in Istanbul and other cities of the realm, often in particularly prescribed manners: Bāyezīd established a lodge for the Naqshbandi shaykh Ahmed Buhārī in Istanbul. ${ }^{80}$ Members of his former household in Amasya and his imperial council and court in Istanbul, Koca Mușțafā Pasha (d. 918/1512) and Ḳapu Ağası Ḥüseyin Ağa (fl. c. 894/1489), were founders of Halveti lodges centered around Friday mosques in Istanbul, the

8o Yüksel, II. Bayezid 247-248, Le Gall, A culture of Sufism 35-62. 


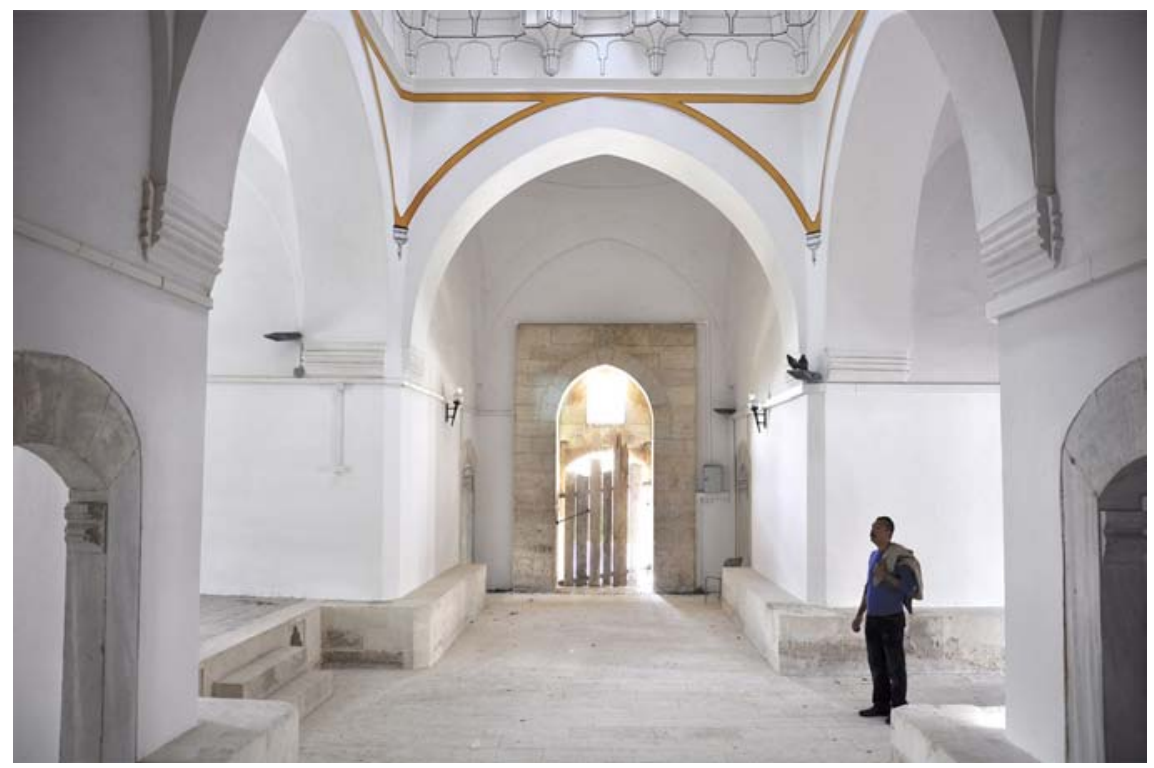

FIGURE 8.11B Edirne, mosque and 'imāret of Bāyezīd II, 893/1487-1488; view of the hospice section flanking the mosque PHOTOGRAPH BY THE AUTHOR

former established for prominent figures of the order who had hailed from Amasya ${ }^{81}$ While earlier waqf documents made explicit references to dervishes' accommodations in urban 'imārets and zāviyes, those comers and goers associated with the more nebulous networks and practices of what Ahmet Karamustafa has termed dervish piety fell outside the patronage net of Ottoman elite patrons of the later ninth/fifteenth century. ${ }^{82}$

The shift in $g \bar{a} z \bar{\imath}$ constructions during these same decades also underlines the changing semiotics of patronage. Unlike Gāzī Mihāl, who founded an 'imāret at the edge of Edirne in 825/1421-1422, later Mihāloğlus such as 'Alī and Ahmed Beys turned to sponsor saints' shrines deep in the forested countryside of the Eastern Balkans. Among these shrines, built in the Mihāloğlus' immediate area of influence, are the complex of Otman Baba in southern Bulgaria and that of Demir Baba in the Deliorman, each centered around the mausoleum of

81 On the political context, see Karataş, The city as historical actor, 103-118; Curry, The transformation, 273-276; on the foundations, Yürekli, Between public and private; Kafescioğlu, Constantinopolis/Istanbul 220-225.

82 Karamustafa, Origins of Anatolian, 84 ff.; and Karamustafa, Antinomian Sufis; Terzioğlu, Sufis in the age of. 
an abdāl of Rum. Mihāloğlu expanded their benefaction of dervish piety into Anatolia, and sponsored constructions in the shrine complexes of Seyyid Gāzì and Ḥâccī Bektaş, exactly at the time when the Ottoman center had begun pronounced efforts to control and to co-opt dervish groups, connected to various cults of saints and discontented both with the emerging Ottoman configuration of power and its religious politics, into the fold of Bektashism in the making. ${ }^{83}$ Members of another notable frontier dynasty, the sons of Evrenos Gāzī, seem to have followed trends of the imperial center more closely. They founded a Friday mosque in Iannitsa in 1498, the dynasty's stronghold, and extended an invitation to and hosted the Naqshbandi shaykh and scholar 'Abdullāh-ı İlāhī here and at nearby Naoussa. ${ }^{84}$

The early years of Süleymān's rule brought Kemālpaşazāde Şemsüddīn Aḥmed (also known as Ibn Kemāl), a prolific scholar and prominent member of the religious hierarchy, to the post of chief mufti, a position he held from 932/1526 until his passing in 940/1534. ${ }^{85}$ Within the corpus of works Kemālpaşazāde published through a long scholarly career are also treatises that delineate his views on religious identities and practices that fell outside the fold of Sunni Islam and of the Hanafi creed, including those on Sufi notions and practices that he found nonconforming to the sharia. ${ }^{86}$ Changes in Kemālpaşazāde's relationship to Sufi orders and their masters in Istanbul have been noted, his earlier hostility evolving into intimate connections to figures like Sünbül Sinān and İbrahīm Gülşenī. ${ }^{87}$ His corpus of fatwas, which grant considerable space to Sufism and Sufi ritual, nevertheless document a set of austere views on the topic. Of particular importance to this paper are those involving ritual space and the identities of the Sufis. ${ }^{88}$

83 Yürekli, Architecture and hagiography; Kiprovska, The Mihaloğlu family; Tanman, Demir Baba; Antov, The Ottoman "wild west" 71-93.

84 Umur, Reconstructing Yenice-i Vardar 112-125.

85 On Kemālpaşazāde, see Turan et al., Kemalpaşazade. On his career and role as chief mufti, see also Repp, The mufti of Istanbul; Atçl, The Safavid threat 301-304; Inanır, İbn Kemal'in fetvaları.

86 References in İnanır, İbn Kemal'in fetvaları 67, fn 227.

87 Öngören, Osmanlılar'da tasavvuf 344-348.

88 Öngören, Osmanlılar'da tasavvuf 369-380; İnanır, Ibn Kemal'in fetvaları 67-75. In at least one collection of his fatwas, opinions regarding Sufi ritual have been collected under a separate heading; Kemālpaşazāde, Fetāvā-yı İbn Kemāl 78 b: "Sūfilerin zikr ve devrānına müte'allik șorular." 
Among the body of Kemālpaşazāde's opinions that address questions of Sufi $\underline{z i k r}, \operatorname{sem} \bar{a}$, and devrān are numerous fatwas that take issue with prayer leaders who condoned practices of $\underline{z} i k r$. Fatwas state that such an imam would not be considered legitimate and that prayers performed with his leadership would be null. ${ }^{89}$ That Sufi ritual in mosques was a weighty issue is suggested by one fatwa that mentions Zeyd climbing the pulpit in a mosque to preach on the erstwhile and continued lawfulness of dance ( $\mathrm{rakss}$ ). Kemālpaşazāde's opinion: the Muslims who are present should take the impostor down the pulpit and out of the mosque. ${ }^{90}$ Plural practices in the masjid (and possibly, the masjid section of an 'imāret) were no more admissible: Sufis loudly performing $z i k r$ while Quran reading and interpretation continued in the masjid were to be warned and stopped. ${ }^{91}$ In all, Kemālpaşazāde's fatwas make clear that Sufi ritual in mosques and masjids was now deemed unacceptable and that mosque imams were expected to conform to the new demarcation of their roles. ${ }^{92}$ One must also consider that the chief mufti issued these fatwas in an Istanbul that housed Halveti mosque-lodges that used the monumental domed naves of converted Byzantine churches as ritual and congregation spaces, among them the Kooca Mușțafā Paşa (S. Andrei in Kriesei) and Küçük Ayasofya (ss. Sergius and Bacchus).

The Sufi's body and voice were objects of stern supervision and control in Kemālpaşazāde's reordering of devotional practice. His fatwas often equate moving in a circle (devrān) and dance (rakss) and provide a number of dictionary-like definitions for rakṣ: "žikr through moving in a circle (devrān), bending one's head and waist, moving one's hands and feet." Rakș during Sufi ritual appears to be perceived as a problem specifically in urban contexts; Kemālpaşazāde repeatedly asked for those who insisted on practicing $\underline{z} i k r$ in the form of dance to be subjected to fierce punishment, deemed unbelievers ( $k \bar{a} f i r)$, and deported from the city. ${ }^{93} \mathrm{~A}$ Sufi was expected, he ruled, to perform $\underline{z i k r}$ as if he was in the presence of sultans, sitting in dignified quietude and with perfect manners. ${ }^{94}$ The mufti took issue with giving alms to those who claimed devrān to be lawful, suggesting that the objects of this particular fatwa (and perhaps

\footnotetext{
89 Kemālpaşazāde, Fetāvā-yı İbn Kemāl 79b; Kemālpaşazāde, Mecmūatü'l-fetāvā 6a.

$90 \quad$ Kemālpaşazāde, Fetāvā-yı İbn Kemāl 79a.

91 Kemālpaşazāde, Mecmūáü̈l-Fetāvā $7 \mathrm{a}$.

92 The fatwas resonate in Ebū's-su'ūd's fatwas discussed by Necipoğlu with some differences, one striking divergence being Ebū's-su'ūd's inclination to stipulate the execution as heretics of those Sufis practicing unacceptable forms of $z i k r$.

93 Kemālpaşazāde, Fetāvā-yı İbn Kemāl 79b, 8oa; Kemālpaşazāde, Mecmū'atü'l-fetāoā 6a.

94 Kemālpaşazāde, Mecmü'atül-fetā $v \bar{a}$ 6a. Turan, quoting from 'Ațāīi, notes that Kemālpaşazāde also had a fatwa that condoned devrān; Turan, Kemalpaşazade.
} 
some of the others) were mendicant dervishes rather than Sufis connected to an established order and therefore beneficiaries of a network of endowments. Numerous temporal phrases and comparisons in the fatwas betray a consciousness of the past and present of religious praxis. One fatwa possibly referred to 'Alī Cemālī Efendi (d. 932/1525-1526) who occupied the post of chief mufti prior to him, and who, with intimate personal and familial ties to the Halvetiye, was expressly more permissive in his writings and opinions regarding the bodily dimension of Sufi ritual. Kemālpaşazāde ruled that his current opinions regarding devrān in mosques would override those of the former mufti. ${ }^{95}$ At issue was a passage, where devotional practices and their sites were concerned, from an earlier to a novel corporeal and spatial regime. ${ }^{96}$

Süleymān the Lawgiver and Sinān his chief architect took permanent care of the matter (at least as far as the physical spaces of worship were concerned) and in the following decades buried multifunctional buildings that sheltered plural ritual and devotional practices in early Ottoman memory. With the exception of the Aleppo mosque of Hüsrev Pasha (953/1546-1547), none of the 100 plus mosques for which Sinān claimed authorship feature attached hospice rooms. ${ }^{97}$ Süleymān's Istanbul complex was in significant ways modeled after that built by Mehmed II in the 86os/146os and duplicated the firm separation of its mosque from its accommodative spaces. This arrangement was to be followed by all dynastic and elite mosque builders of the Ottoman realm through the early modern era. During these decades Ebū's-su'ūd Efendi (d. 982/1574), Kemālpaşazāde's former student and his successor in the post of chief mufti, issued numerous fatwas prohibiting Sufi ritual in mosque spaces and in the masjids of zāviyes. Enforcing stricter confessional segregation in devotional spaces was also an issue: one decree from the center banned non-Muslims from using hospice rooms attached to a mosque. ${ }^{98}$ During these decades also, orders from Istanbul decreed the remodeling of Bursa's royal zāviyes so that

95 Fetāoā-yı Kemālpaşazāde 6a. On 'Alī Cemālī Efendi, see Küçükdağ, II Bayezid 51-81; Görkaş, Zenbilli Ali Efendi'nin. 'Alī Cemālī Efendi, Mecmūáa-i fetāvā.

96 Regulating the use of space in mosques did not concern Sufi practices only: one manuscript of the Hulviyāt-ı şăhi includes a fatwa stating that commoners should not form circles in Friday mosques to recite battle epics and stories; İsfendiyāroğlu, Hulviyāt-ı şāhī, İstanbul Üniversitesi Kütüphanesi Ms T 5849, 275v, cited in Necipoğlu, The age of Sinan $5^{2-53 .}$

97 On Hüsrev Pasha's Aleppo foundation, see Kafescioğlu, In the image of Rüm 71, 83-86; Watenpaugh, The image of an Ottoman city 6o-77; Necipoğlu, The age of Sinan 472-475. On departures from earlier mosque and hospice construction during Süleymān's reign, see ibid., ${ }^{2-57}$. Ünver Rüstem's chapter in the present volume explores post tenth/sixteenth century reformulations in the architecture and symbolism of the sultanic mosque.

98 On Ebū's-su'ūd's fatwas regarding Sufi ritual in mosques, and on a court edict banning 
those coming and going (ayende $u$ revende) would not disturb the space now allocated only to normative religious practice. Çelebi Meḥmed's royal zāviye in Bursa was now and hereafter the Green Mosque.

The textual and architectural evidence on the conversion of imärets into congregational mosques reveals a century-long sequence of institutional and architectural interventions, which changed these buildings in ways that have continued to shape our modern perceptions of them. Conversion of an 'imāret into a mosque was effected at the institutional level by the appointment of a $h a t i \bar{b}$, a reader of the Friday sermon, which remained a prerogative of the imperial center. The installation of a minbar would follow the appointment of a hațīb. Other spatial interventions were often more complex and have unfortunately attracted relatively little attention, which continues to hinder a full understanding of the original layouts and uses of many of the imarrets, and aspects of their afterlives as mosques. Aptullah Kuran's, and later, Sedat Emir's careful on-site examinations have revealed that many buildings underwent a radical restructuring of their interior spaces, in numerous cases involving the taking down of partition walls separating the 'imarret's main domed hall from the hospice rooms. ${ }^{99}$ These works have revealed that many imārets, including iconic examples of the "type," such as those of Orhan and Murād II in Bursa, underwent interventions that incorporated side rooms into the main space by turning them into eyvāns, and giving the buildings their present three-eyvān schemes that are frequently reproduced in scholarship (figures 8.12, 8.13, and 8.14). ${ }^{100}$ The function of the main domed hall, too, was altered in the process

non-Muslims using hospice rooms of a convent-mosque in the town of Çorlu and directing them to a distant caravanserai, see Necipoğlu, The age of Sinan $5^{2-53}$.

99 Kuran, The mosque 124-125, 132-133; Emir, Erken Osmanlı mimarlığında; Emir, Erken Osmanlı mimarlığında ii, ${ }_{18-5}$; Emir, Reconstructing an early Ottoman building; Emir, Bursa Ali Paşa zaviyesi; Emir, Edirne Mihal Bey zaviyesi.

100 Kuran observed that seven out of the ten structures he classified as "cross-axial eyvān mosques" (those buildings that incorporated side eyvāns in addition to the prayer eyvān), present structural evidence for this type of intervention; Kuran, ibid. (These are the Orhan Mosque in Bursa, Mezid Bey in Edirne, Muradiye in Edirne and in Bursa, İshak Pasha in İnegöl, and Hamza Bey in Bursa); Kuran, The mosque 132-136. This leaves four sultanic 'imārets of the later eighth/fourteenth century and the turn of the ninth/fifteenth, built by Murād I, Bāyezīd I, and Meḥmed I in Bursa and in Edirne, as a special group of royal patronage incorporating a three-eyvān scheme. Instances whereby the interior was "expanded" through tearing down walls separating the main hall from side rooms are discussed in detail in Emir, who provides additional structural details that betray interventions to the building fabrics, Erken Osmanlı mimarlığında 147-156. Gabriel in 1958, and Eyice in 1964, too, observed, based on their respective surveys of the Murād II 'imāret, that the curtain walls separating hospice rooms from the main hall had been taken down during a later intervention; Gabriel, Brousse 108; Eyice, İlk Osmanlı devrinin 38. 


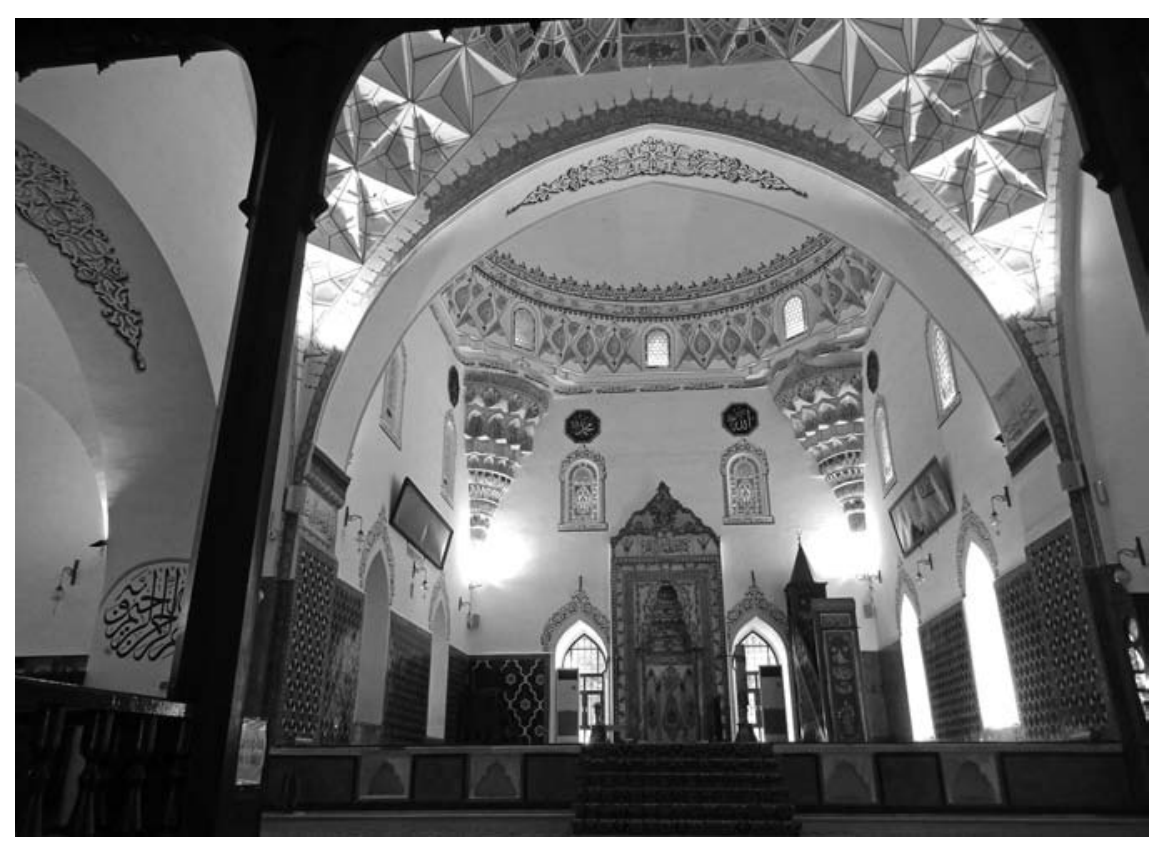

FIGURE 8.12A Bursa, zāviye/'imāret of Murād II (830/1426) converted into a congregational mosque in the later tenth/sixteenth century: interior toward the prayer eyvān PHOTOGRAPH BY THE AUTHOR

of conversion, becoming part of the prayer space as was the case of newly built mosque-hospices sponsored by the new kül elite, rather than a central hall that was the circulation node within the building whether one headed to the prayer hall or to one of the tābhāne rooms furnished with fireplace and cupboards.

As was the case in newly built mosque-hospices, circulation directed to the rooms was an issue. In 'imārets converted into mosques, new side entrances that connected the hospice rooms directly to the building's exterior, some enlarged from extant windows, were a novel feature that assured that dervishes and travelers no longer trespassed the mosque space to reach their private quarters. A court record of 958/1552 on the conversion of the Yeşil imāret captures with remarkable precision the nature of the intervention that was envisioned, recording a petition by the waq $f$ superintendent for arrangements in the mosque space and its gates of entry. The central pool and fountain in Çelebi Mehmed's (now) exalted mosque needed to be carried outside of the building, as used water overflowed to the area around it and created a state of pollution, which prevented the worshippers from praying here (i.e., in what was once the $z \bar{a} v i y e$ 's lantern-domed central hall). Since the mosque is in a densely inhabited area, the petition reads, the Friday congregation is large. If the said pool is trans- 


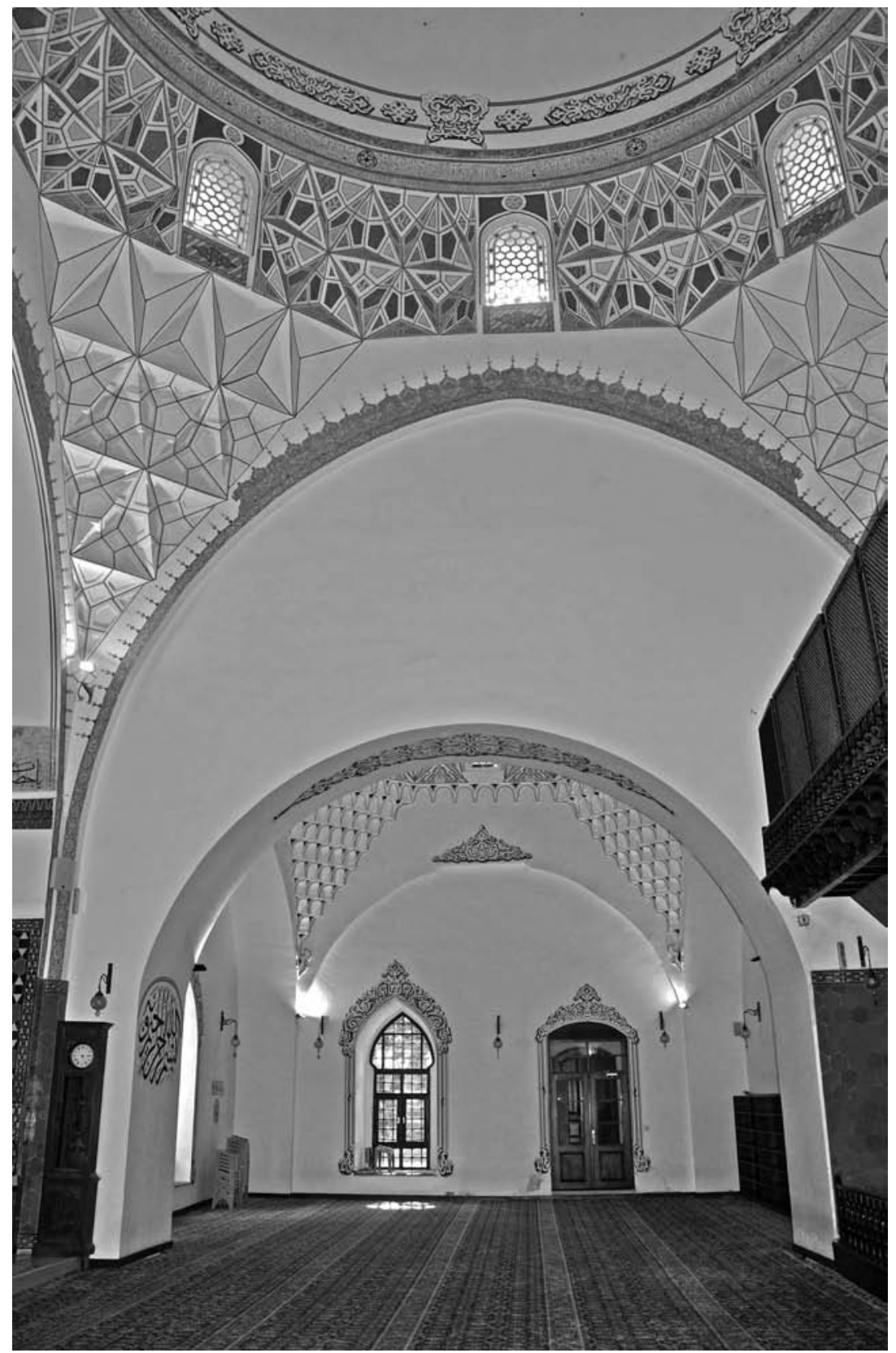

FIGURE 8.12B Bursa, zāviye/imāret of Murād II (830/1426) converted into a congregational mosque in the later tenth/sixteenth century: interior toward the hospice room transformed into an eyvān PHOTOGRAPH BY THE AUTHOR 


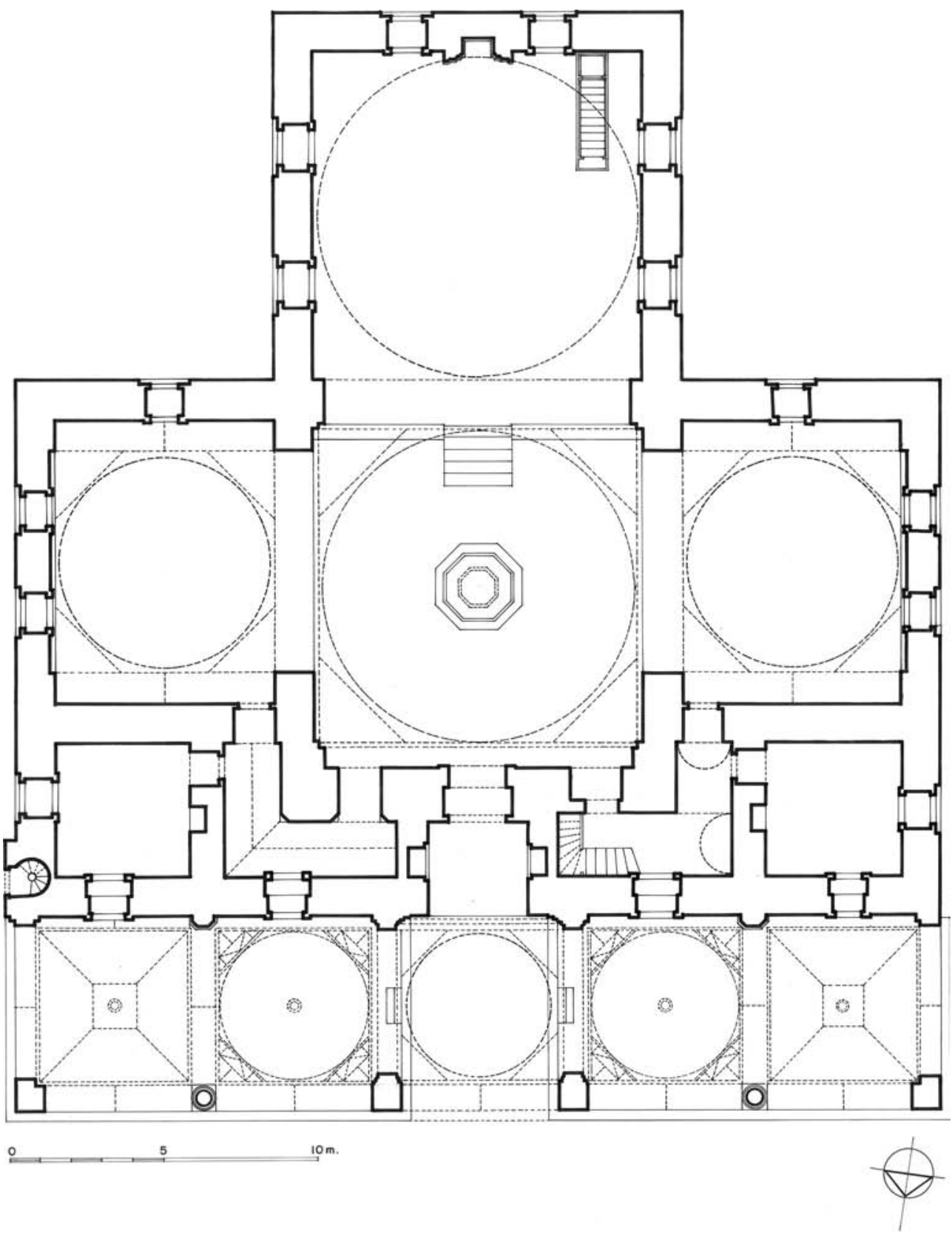

FIGURE 8.13 Bursa, zāviye/'imāret of Murād II (83o/1426) converted into a congregational mosque in the later tenth/sixteenth century, plan BY PERMISSION OF THE BOĞAZIÇI UNIVERSITY APTULLAH KURAN ARCHIVE 
$\oplus$
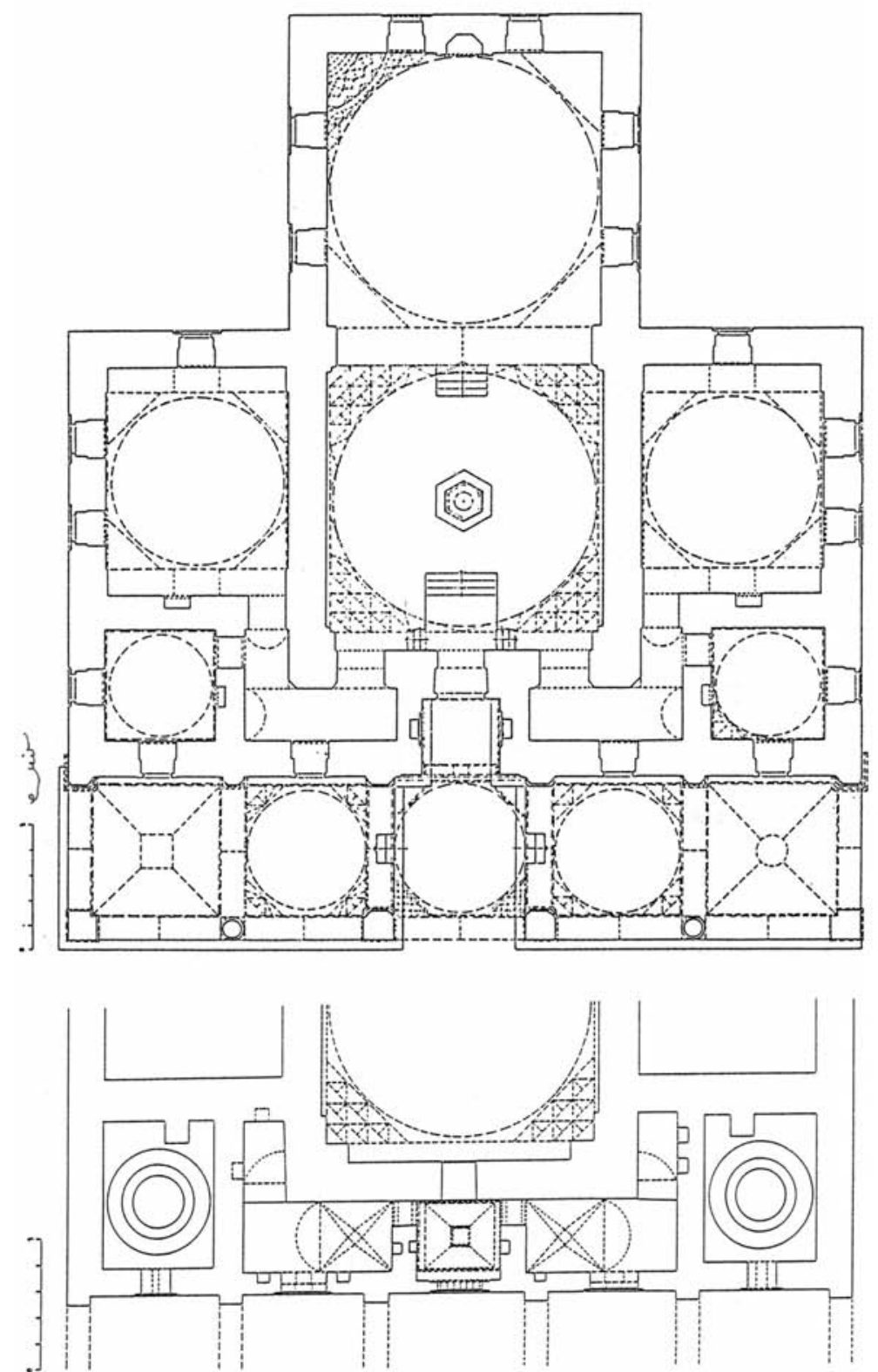

FIGURE 8.14 Bursa, Muradiye zāviye/'imāret reconstitution by Sedat Emir showing the original layout of the interior FROM SEDAT EMIR, ERKEN OSMANLI BY PERMISSION OF THE AUTHOR 
ported to the outside courtyard of the mosque, which was newly constructed in the style of [the courtyards of] other sultanic mosques, and if new gates to the hospice rooms are opened directly to the exterior of the building, the interior of the exalted mosque will not be a passageway for those who come and go; moreover, the space will be clean and therefore appropriate for Muslims to pray in. ${ }^{101}$ The proposed changes were not fully implemented, and Yeşil Cami did not undergo the interventions that many converted 'imārets were subjected to: the fountain under its main dome remains in place; and if, as Ayverdi suggested, one of the windows was enlarged to be used as a lateral entrance, the alteration was later reversed to restore the integrity of the building's skillfully designed and ornamented side facades.

The pronounced attention to distinctly delineating the spatial boundaries of requisite prayer, in line with the newly formulated requirements of orthopraxy, paralleled the need for new congregational spaces for the Muslims in growing urban populations. ${ }^{102}$ A record of $984 / 1576$ documents the demands for the enlargement $\left(\right.$ tevs $\left.\bar{\imath}^{\top}\right)$ of the prayer hall of "Sultan Orhan's exalted mosque in Bursa," as the congregation was not fitting in the prayer space, a hindrance particularly on cold winter days. ${ }^{103}$ The petition for the enlargement of the mosque space is in line with Kuran's and Emir's analyses of the building: separately, they have observed that the current side eyvāns were originally hospice rooms that were incorporated into the main space at a later date, through the destruction of the partition walls separating the domed main hall from the

101 Bursa court records, A58/63, 5a, cited in Ayverdi, Çelebi ve II. Sultan Murad 50; and transcribed in Emir, Erken Osmanlı mimarlığında 230-231. The record notes that 10,000 akçes were allotted for the projected interventions. Ayverdi suggests that the window of the northeastern room was enlarged to function as a door and later restored to its original.

102 Emir has suggested that population growth was the primary reason behind conversions of 'imārets into mosques; Necipoğlu underlines issues of Sunnitization, alongside rising urban populations, in connection to the boom in Friday mosque construction and conversions of extant structures; Emir, Erken Osmanlı mimarlığında 289-291 and passim; Necipoğlu, The age of Sinan $5^{2-57}$.

103 вОА, Mühimme defteri 28, 165, published in Dağlığlu, 16. asırda Bursa; and Emir, Erken Osmanlı mimarlı̆ında ii, 22. The building underwent an earlier restoration, as indicated by its inscription $(820 / 1417)$. Ayverdi has discussed this intervention due to the damage the building suffered during the Karamanid invasion of Bursa in 816/1413. According to Ayverdi, architectural evidence suggests that the 820/1417 restoration did not result in a significant alteration in the building's layout; Ayverdi, Osmanlı mimarisinin 8o-82. Kuran argues that the building originally featured vaulted spaces as in Orhan's İznik foundation and was covered with a domed superstructure during the $820 / 1417$ renovation. He also suggests that the partition walls of the hospice rooms may have been torn down at that date. While the dating is not correct, Kuran's observation agrees with the intervention mentioned in the Mühimme document dated 984/1576; Kuran, The mosque 98-10o, 132-133. 
side rooms. (fig. 8.15) ${ }^{104}$ That these documents recording interventions to two of Bursa's royal 'imārets already refer to the buildings as cāmici $i$ şerîf (exalted mosque) suggests that at the time the architectural changes were implemented, the appointment of a Friday sermon reader, and the building's change of status from 'imāret into mosque had already taken place. A minaret was added to Murād II's 'imāret-turned-mosque in 1002/1594. This was at least four, or possibly more, years after the building's conversion into a congregational mosque, which also involved the transformation of two of its hospice rooms to side eyvanns opening onto the central hall. ${ }^{105}$ The construction of a minaret gave an unambiguous architectural form to the new denomination, altering the visual identity of the zāviye /'imāret.

Between the conversion and "enlargement" of Skopje's İshāạ Bey zāviye, on or before 925/1519, and the conversion of Bursa's Hamza Bey 'imāret in 1023/1614, in order to provide the neighborhood with a space for Friday prayer "in line with the jurisdiction of the Hanafi imams,"106 the majority of T-type imärets in the Ottoman domains (whether they had originally incorporated a prayer hall with a mihrab or not, and whether their endowments included allowances for masjid personnel or not), were converted into congregational mosques. ${ }^{107}$ The story of the early Ottoman 'imarret through the long tenth/sixteenth century captures in full light the spatial, social, and institutional dimensions of processes of confession building, in particular measures directed at consolidating Hanafi-Sunni praxis in cities. This involved excluding the devotional practices of those groups who located themselves outside of Sunni Islam as state religion. Measures aimed to reshape the spatial and corporeal regimes of city dwellers, and sought to create and keep intact congregational communities attached to particular nodes, whether masjids or Friday mosques. Derin Terzioğlu has noted that acts toward Sunnitization and confessionalization in

104 Kuran, The mosque 132-133; Emir, Erken Osmanlı mimarlığında ii, 39-43.

105 Emir, Erken Osmanlı mimarlığında 147. A Yorgaki Kalfa was summoned to Istanbul in relation to the minaret project. He is not referred to as hāsșa mímārı, suggesting that a local architect was entrusted with the construction, rather than one sent from Istanbul.

106 "Eimme-i hanefiyye'nin kavli üzere," Bursa court records, no. 227, f. 125, no. 225, f. 13, cited in Ayverdi, Fatih devri iii, 89. The records also site the difficulty experienced by mahalle residents in reaching the Friday mosque, which was at a distance. Hamza Bey died in 866/1462 at the hands of Hunyadi Janos; the undated building was likely completed prior to that date, during or before the reign of Mehmed II.

107 At the time Evliyā Çelebi visited Dimetoka (Didymoteichon), he noted several zāviyes that were "suitable for conversion into mosques" (câmi' olmağa müsta id zâviyeler), suggesting that the process continued; Evliyâ Çelebi, Seyahatnâme viii, 3o. On mosque construction and conversions in Rumelia in through the tenth/sixteenth century, see the chapter by Grigor Boykov in this volume. 


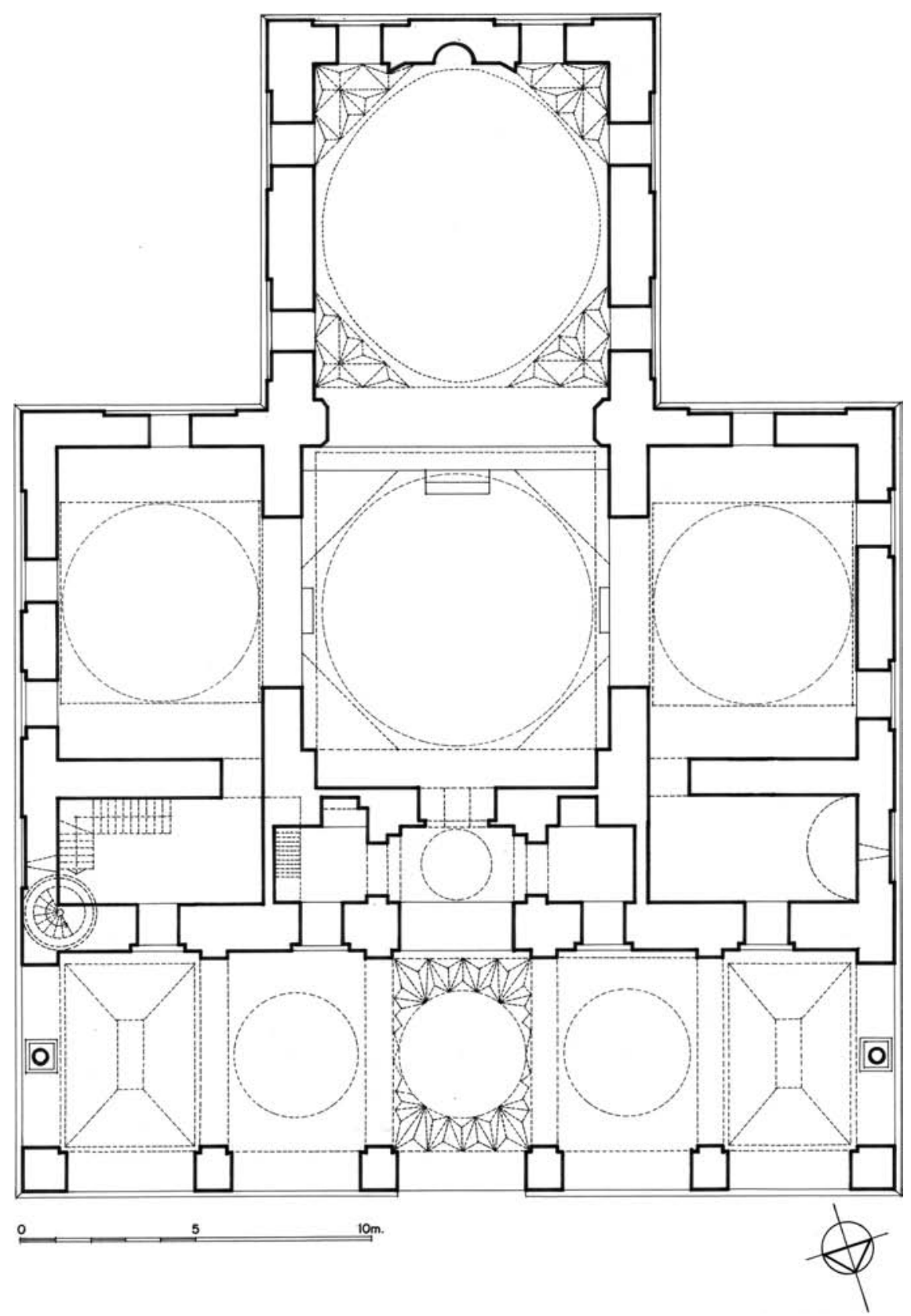

FIGURE 8.15A Bursa, Orhan 'imāret (740/1339-1340) converted into a congregational mosque ca. $984 / 1576$; plan

BY PERMISSION OF THE BOĞAZIÇI UNIVERSITY APTULLAH KURAN ARCHIVE 


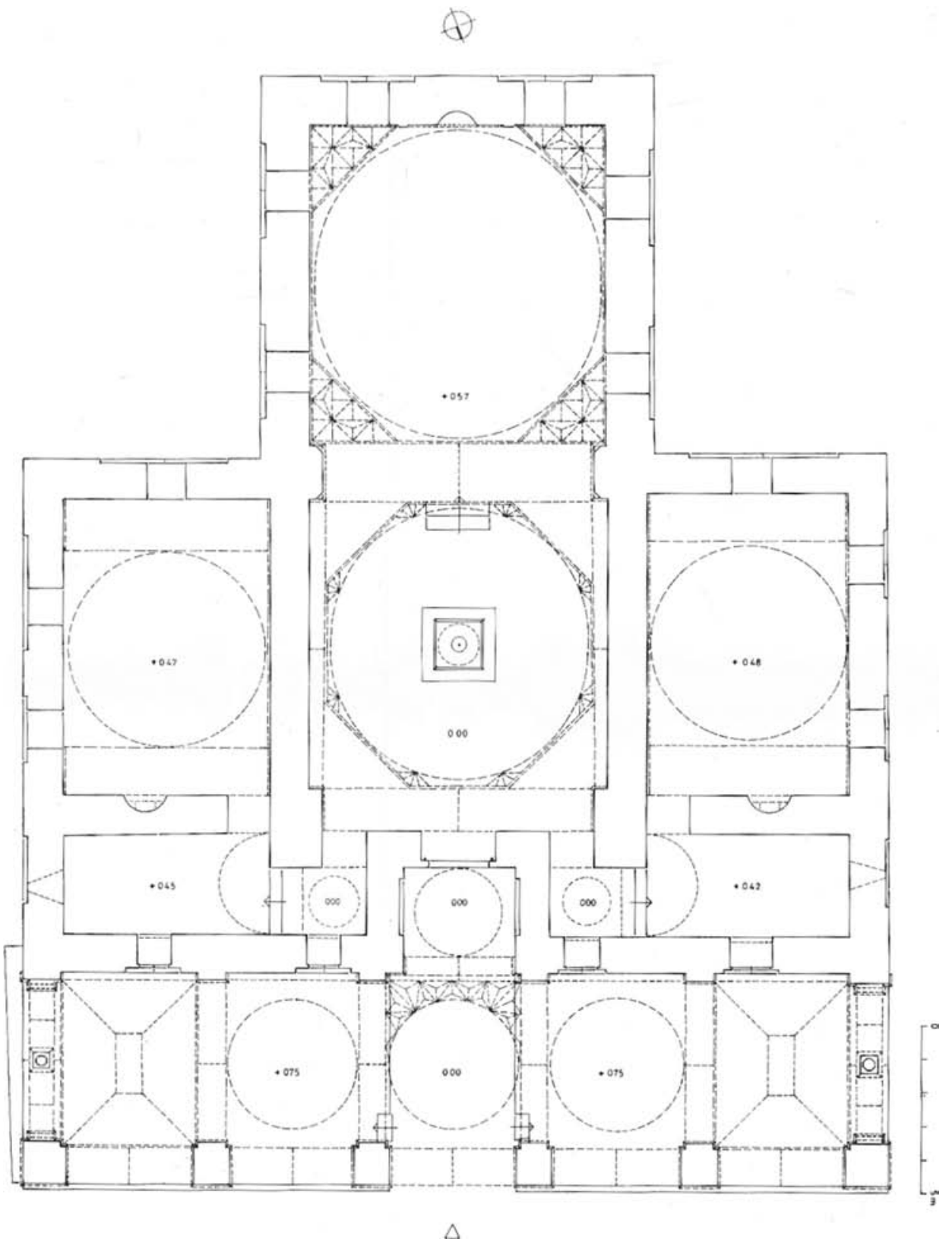

FIGURE 8.15B Bursa, Orhan 'imāret (740/1339-1340) converted into a congregational mosque ca. 984/1576; reconstitution by Sedat Emir showing the original layout of the interior FROM SEDAT EMIR, ERKEN OSMANLI, BY PERMISSION OF THE AUTHOR 


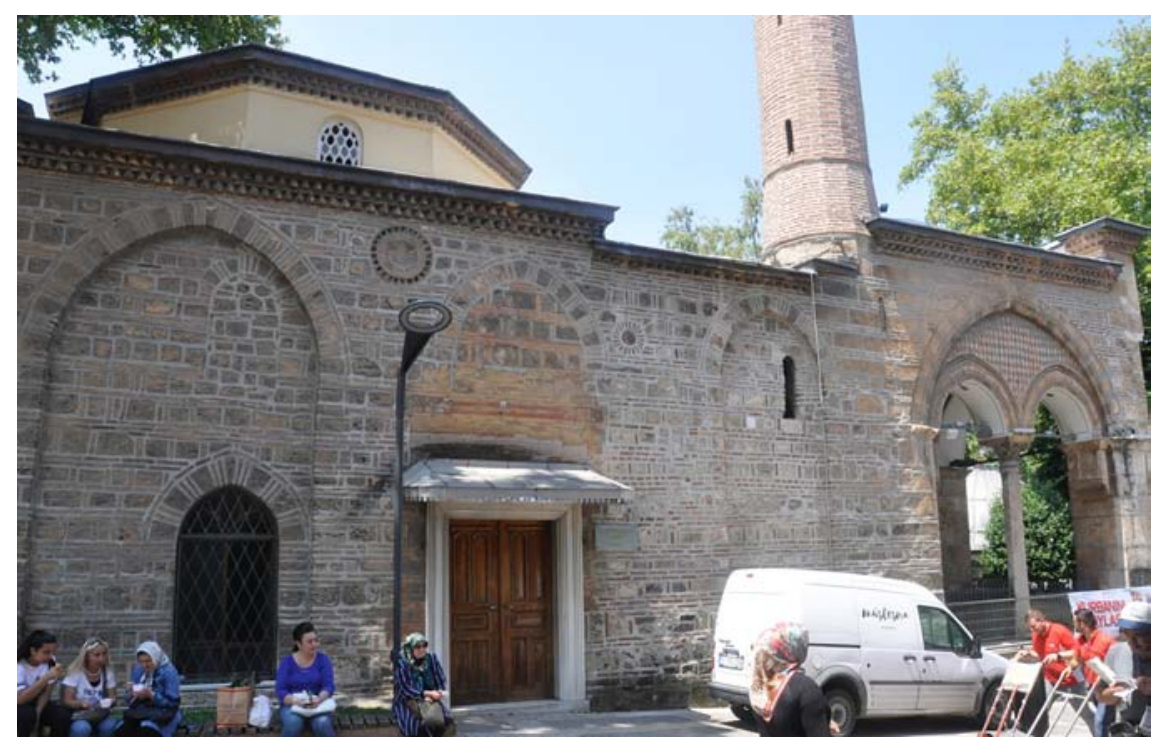

FIGURE 8.15C Bursa, Orhan 'imāret (740/1339-1340) converted into a congregational mosque ca. 984/1576; view from north, with later addition of side entrance PHOTOGRAPH BY THE AUTHOR

the Ottoman domains were directed toward Sunnis as much as toward nonSunni communities. ${ }^{108}$ The evidence presented in this paper with regard to the afterlives of the early Ottoman 'imäret and largely concerning the central and western areas of the lands of Rum supports this view.

The institutional and spatial interventions to spaces of devotion and the disciplinary measures that accompanied them were directed at the corporeal and spatial regimes of city dwellers. Architecture conformed to the religiopolitical vision of the Ottoman center; the multifunctional 'imäret that offered no clear demarcation between sacred and profane, and between normative religious practice and Sufi ritual, was rendered a thing of the past. Did the imāret converted into mosque and the new architecture of the congregational mosque with its unified space (a powerful Ottoman legacy into the twenty-first century) alongside the plethora of prescriptive texts that sought to define usage of mosques succeed in creating a public that conformed to the disciplinary measures of the center? Not completely, if we are to consider how central issues of Sufi ritual and ritual in mosques were to the Kadizadelis and their opponents in the eleventh/seventeenth century, or if we were to attend Niyāzi-i Mıṣni in the

108 Terzioğlu, How to conceptualize, $320-321$. 
Bursa of the 1080s/1670s, where he held zikr circles in a neighborhood masjid, and also, clashes with the imam notwithstanding, in the celebrated Ulucami. ${ }^{109}$

Zâviye and the mosque-hospice remained buried in the early Ottoman past until a modern evocation of a now idealized era of Ottoman beginnings ushered them into the representational spaces of late empire. Ironically perhaps (at a moment when the aesthetics of Bursa and particularly of the Yeşil complex were all the rage), it was not the zāviye but the mosque with the hospice rooms that was recreated in 'Abdü'l-hamìd II's Hamidiye Mosque attached to the Ylldiz Palace in 1886, a building that has been described by Ahmet Ersoy as "a tribute to the long abandoned archetype of the T-plan building, an exceptional product of pure historicist reflection."110 A republican, and infinitely more solemn, revival when compared to the Yildız Hamidiye Mosque, has recently been on view at Salt Galata: an unrealized project by the architect and restorer Ali Saim Ülgen (d. 1963). His is a proposal dating to the 195 os for a mosque in Ankara's Yenişehir district, modeled after royal mosques with hospice rooms, such as those of Bāyezīd II in Edirne and Selīm I in Istanbul. ${ }^{111}$ It captures a modern imagining of the Ottoman past at a time when architects and scholars were engaged in debate regarding the original functions of the T-plan 'imārets with hospice rooms and the intentions of their builders. As in scholarly pursuits, in architectural practice of the later nineteenth and twentieth centuries, too, the mosque, it seems, overshadowed the imäret/zāriye. Architectural and written archives remain and bear witness to the plural and layered histories of these buildings and their spatial and conceptual afterlives within the wider geography of Rum, and through different temporalities.

\section{Acknowledgments}

My sincere thanks to Derin Terzioğlu, Tijana Krstić, and Gülru Necipoğlu for the insightful comments and observations they have offered on this article. I would also like to thank the organizers, Maximilian Hartmuth, Zeynep Oğuz, and Marianne Boqvist, and participants of the workshop "Revisiting the Tshaped 'zaviye/'imaret': buildings and institutions in early Ottoman architecture," which was held at the Swedish Research Institute, Istanbul in 2013, and where I presented a shorter version of this paper.

\footnotetext{
109 Terzioğlu, Sufi and dissident 117. Terzioğlu notes that a lodge was later built for Mișrī.

110 Ersoy, Aykırı binanın 110.

111 Modern Türkiye'nin Osmanlı mirasını keşfi: Ali Saim Ülgen arşivi, Exhibition at Salt, Istanbul, 8 February-24 March 2013; Salt Araştırma, cat. no TASU PAO540001.
} 


\section{Bibliography}

\section{Primary Sources}

B OA: Başbakanlık Osmanlı Arşivi [now T.C. Cumhurbaşkanlığı Devlet Arşivleri Başkan-

lığı] Maliyeden Müdevver 162/5

Vakıflar Genel Müdürlüğü Arşivi, 2088.

Aktan, B., Devletoğlu Yusuf'un Vikaye tercümesi (İnceleme, metin, dizin), PhD diss., Atatürk Üniversitesi 2002.

'Alī Cemālī Efendi, Mecmū'a-i fetāvā, Süleymaniye Kütüphanesi, ms Fatih 2388.

Aşık Mehmed, Menâzirü'l-'avâlim, ed. M. Ak, Ankara 2007.

Ayverdi, E.H., Yıldırım Bayezid'in Bursa vakfiyesi ve bir istibdalnamesi, in Vakıflar dergisi 8 (1969), 37-46.

Balata, R.Y., Hunkarnāma (Tavārikh-i Āl-i Osmān) Mīr Sayyīd 'Alī b. Muzaffar-i Macālī, PhD diss., Istanbul Üniversitesi 1992.

Barkan, Ö.L. and E.H. Ayverdi, Istanbul vakıfları tahrîr defteri 953 (1546) târîhli, Istanbul 1970.

Bidlisî, İ., Heşt Behişt: VII. ketîbe: Fatih Sultan Mehmed devri, 1451-1481, ed. M.İ. Yıldırım, Ankara 2013.

Boratav, P.N., Nasreddin Hoca, Istanbul 1996.

Duman, M., Nasreddin Hoca ve 1616 fıkrası, Istanbul 2018.

Enverī, Düstūrnāme-i Enverī, ed. M.H. Yinanç, Istanbul 1929.

Ergin, O. (ed.), Fatih Sultan Meḥmed'in vakfiyeleri, Istanbul 1945.

Evliyâ Çelebi, Evliyâ Çelebi seyahatnâmesi, ed. R. Dankoff et al., 10 vols., Istanbul 19962007.

Gedik Aḥmed Paşa vakfiyesi, Vakıflar Genel Müdürlüğü Arşivi, 2088.

Gökbilgin, M.T., Murad I. tesisleri ve Bursa imareti vakfiyesi, in Türkiyat mecmuası 10 (1953), 217-222.

Ibn Battuta, The travels of Ibn Battuta, trans. H.A.R. Gibb, 2 vols., Cambridge 1962.

İsfendiyāroğlu İsmā̄̄l Bey, Hulviyāt-ı şāhī, Süleymaniye Kütüphanesi, Ms Serez 688.

Kemālpaşazāde, Fetāvā-yı İbn Kemāl, Süleymaniye Kütüphanesi, Ms Aşir Efendi 270.

Kemālpaşazāde, Mecmū'atü'l-fetāōa, Süleymaniye Kütüphanesi, Ms Atıf Efendi 2835 .

Kutbe'd-dîn İznikî, Mukaddime, ed. K. Üstünova, Bursa, 2003.

Küçük Abdal, Otman Baba Velayetnamesi (tenkitlimetin), ed. F. Kılıç et al., Ankara 2007.

Mu'ālī, Hunkārnāme, Topkapı Sarayı Müzesi Kütüphanesi, Ms Hazine 1417.

Öz, T. (ed.), Zwei Stiftsurkunden des Sultan Mehmed II, Fatih, Istanbul 1935.

Tamer, V., Fatih devri ricalinden İshak Paşa’nın vakfiyeleri ve vakıfları, in Vakıflar dergisi 4 (1958), 107-124.

Yılmaz, C. (ed.) İstanbul kadı sicilleri Üsküdar mahkemesi 1 numaralı sicil (H. 919-927 I M. 1513-1521), İstanbul 2008. 
Zengin, Z.S., İlk dönem Osmanlı vakfiyelerinden Serez'de Evrenuz Gazi'ye ait zâviye vakfiyesi, Vakıflar dergisi 28 (2004), 101-120.

\section{Secondary Sources}

Antov, N., The Ottoman "wild west": The Balkan frontier in the ffteenth and sixteenth centuries, New York 2017.

Arnold D. and A. Ballantyne (eds.), Architecture as experience: Radical change in spatial practice, London and New York 2004.

Atçl, A. The Safavid threat and juristic authority in the Ottoman Empire during the 16th century, in IJMES 49 (2017), 295-314.

Ayverdi, E.H., Osmanlımi'mârîsinde Çelebive II. Sultan Murad devri, 806-855 (1403-1451), Istanbul 1972.

Ayverdi, E.H., Osmanlı mi'mârîsinde Fâtih devri, 855-886 (1451-1481), 2 vols., Istanbul 1973.

Ayverdi, E.H., Osmanlı mi'marisinin ilk devri, Istanbul 1966.

Babaie, S. Isfahan and its palaces: Statecraft, Shiism, and the architecture of conviviality in early modern Iran, Edinburgh 2008.

Ballantyne, A., Misprisions of Stonehenge, in D. Arnold and A. Ballantyne (eds), Architecture as experience: Radical change in spatial practice, London and New York 2004, 11-35.

Barkan, Ö.L., Osmanlı İmparatorluğunda bir iskân ve kolonizasyon metodu olarak vakıflar ve temlikler: İstilâ devirlerinin kolonizatör Türk dervişleri ve zâviyeler, in Vakıflar dergisi 2 (1942), 279-304.

Abouseif, D., Change in function and form of Mamluk religious institutions, in AI 21 (1985), 73-93.

Boykov, G., Anatolian emir in Rumelia: İsfendiyaroğlu İsmail Bey's architectural patronage and governorship of Filibe (1460s-1470s), in Bulgarian historical review 1-2 (2013), 137-147.

Boykov, G., The T-shaped zaviye/imarets of Edirne: A key mechanism for Ottoman urban morphological transformation, in Journal of the Ottoman and Turkish studies association 3 (2016), 29-48.

Burak, G., Faith, law and empire in the "age of confessionalization" (sixteenth-seventeenth centuries): The case of renewal of faith, in Mediterranean historical review, 28 (2013), 1-23.

Curry, J., The transformation of Muslim mystical thought in the Ottoman empire: The rise of the Halveti order, Edinburgh 2010.

Çağaptay, S., The road from Bithynia to Thrace: Gazi Evrenos' imaret in Komotini and its architectural framework, in Ch. Bakirtzis, N. Zekos and X. Moniaros (eds.), Byzantine Thrace: Evidence and remains, Amsterdam 2011, 429-442.

Çağaptay, S., Frontierscape: Reconsidering Bithynian structures and their builders on the Byzantine-Ottoman cusp, in Muqarnas 28 (2011), 166-170. 
Çıpa, E., The making of Selim: Succession, legitimacy, and memory in the early modern Ottoman world, Bloomington and Indianapolis 2017.

Sedat Çetintas, Yeşil Camive benzerleri cami değildir, İstanbul 1958.

Dağlıŏlu, H.T., 16. asırda Bursa: 1559-1589, Bursa 1940.

Doğan, A.I., Osmanlı mimarisinde tarikat yapıları, tekkeler, zaviyeler ve benzer nitelikteki fütuvvet yapıları, PhD diss., Istanbul Teknik Üniversitesi, Istanbul 1977.

Emir, S., Bursa Ali Paşa zaviyesi ve erken Osmanlı kentinin imar ve iskan sürecinde zaviyeler, in Arredamento mimarlık 11 (2012), 106-116.

Emir, S., Erken Osmanlı mimarlı̆̆ında çok işlevli yapılar: Kentsel kolonizasyon yapıları olarak zaviyeler, 2 vols., Izmir 1994.

Emir, S., Erken Osmanlı mimarlığında çok işlevli yapılar: Yapısal ve işlevsel bir analiz, PhD diss., Istanbul Teknik Üniversitesi, Istanbul 1991.

Emir, S., Erken Osmanlı mimarlığında zaviyeler. Sırasız metinler, 1: Tipoloji eleştirileri, in Arredamento mimarlık 12 (2012), 12O-123.

Emir, S., Reconstructing an early Ottoman building: Zawiya of Murad II in Bursa, in A. Temimi (ed.), Mélanges Prof. Machiel Kiel, Zaghouan 1999, 269-298.

Ergin, N., C.K. Neumann and A. Singer (eds.), Feeding people, feeding power: Imarets in the Ottoman Empire, Istanbul 2007.

Eyice, S., İlk Osmanlı devrinin dini-içtimai bir müessesesi: Zâviyeler ve zâviyeli camiler, in İtisat fakültesi mecmuası 23 (1964), 3-63.

Ersoy, A., Aykırı binanın saklı kalfası: Hamidiye Camisi ve Nikolaos Tzelepis (Celebis), in Batılılaşan İstanbul'un Rum mimarları, İstanbul 2011, 104-117.

Foss, C., Ephesus after antiquity: A late antique, Byzantine, and Turkish city, Cambridge 1979.

Gabriel, A., Une capitale turque: Brousse, Bursa, 2 vols., Paris $195^{8}$.

Goshgarian, R., Beyond the social and the spiritual: Redefining the urban confraternities of late medieval Anatolia, PhD diss., Harvard University 2007.

Görkaş, I., Zembilli Ali Efendi'nin Sufi deveranını açıklama risalesi ve Türk tefekkürüyle ilişkisi, in Türk dünyası araştırmaları 130 (2001), 221-226.

Grabar, O., The architecture of the Middle Eastern city from past to the present: The case of the mosque, in I. Lapidus (ed.), Middle Eastern cities, Berkeley and Los Angeles 1969, 26-46.

Günüç, F., Türk kültür ve medeniyet tarihinde Fatih Külliyesi, 2 vols, Istanbul 2007.

Hartmuth, M., Building the Ottoman City: A linear or cumulative Process? Lessons from fifteenth-century Skopje, Centre and periphery? Islamic architecture in Ottoman Macedonia, 1383-1520 Research Project No. 26406 Working Paper \# 3 .

Hartmuth, M., A late-fifteenth-century change in the rapport of Friday mosque and Ottoman city? A case study of Macedonia, Centre and periphery? Islamic architecture in Ottoman Macedonia, 1383-1520, Research Project No. 26406 Working Paper \#2. 
İnanır, A. (ed.), İbn Kemal'in fetvaları ışığında Osmanlida İslam hukuku, Ankara 2015. Johansen, B., The all-embracing town and its mosques: Al-miṣr al-ğămic, in Revue de l'Occident musulman et de la Méditerranée 32 (1981-1982), 139-161.

Kafadar, C., Between two worlds: The construction of the Ottoman state, Berkeley and Los Angeles 1995 .

Kafescioğlu, Ç., Constantinopolis/Istanbul: Cultural encounter, imperial vision and the construction of the Ottoman capital, University Park, PA 2009.

Kafescioğlu, Ç., "In the image of Rüm": Ottoman architectural patronage in sixteenthcentury Aleppo and Damascus, in Muqarnas 16 (1999), 70-96.

Kafescioğlu, Ç., The Ottoman capital in the making: The reconstruction of Constantinople in the fifteenth century, PhD diss., Harvard University 1996.

Karamustafa, A., Origins of Anatolian Sufism, in A.Y. Ocak (ed.), Sufism and Sufis in Ottoman society: Sources, doctrine, rituals, Ankara 2005, 67-95.

Karamustafa, A., Antinomian Sufis, in L. Ridgeon (ed.), The Cambridge companion to Sufism, Cambridge 2014, 101-124.

Kemūrāzāde Seyfeddīn Fehmi bin 'Ali, Sarāybosnada ebniyye-i hayriyyenin mușavver tārīhi, Sarajevo [19o8].

Orbay, K., 16. ve 17. yüzyıllarda Bursa ekonomisi: Sultan Çelebi Mehmed Yeşil İmaret'inin mali tarihi (1553-1650), in Ankara Üniversitesi Osmanlı tarihi araştırma merkezi dergisi (2007), 126-158.

Kiel, M., The oldest monuments of Ottoman-Turkish architecture in the Balkans, in Sanat tarihiyıllı̆̆ı 12 (1982), 117-144.

Kiprovska, M., The Mihaloğlu family: Gazi warriors and patrons of dervish hospices, in Jos 32 (2015), 193-222.

Krstić, T., Contested conversions to Islam: Narratives of religious change in the early modern Ottoman Empire, Stanford 2011.

Krstić, T., From shahada to 'aqìda: Conversion to Islam, catechisation and Sunnitisation in sixteenth-century Ottoman Rumeli, in A.C.S. Peacock (ed.), Islamisation:Comparative perspectives from history, Edinburgh 2017, 296-314.

Krstić, T., Illuminated by the light of Islam and the glory of the Ottoman sultanate: Narratives of conversion to Islam in the age of confessionalization, in Comparative studies in society and history, $5^{1}$ (2009), 31-63.

Koch, D., Changing building typologies: The typological question and the formal basis of architecture, in The journal of space syntax, 5 (2014), 168-189.

Kuban, D., Osmanlı mimarisi, Istanbul 2007.

Kuran, A., The mosque in early Ottoman architecture, Chicago 1968.

Kuran, A., Anadolu medreseleri, Ankara 1969.

Kuran, A., Edirne'de Ylldırım camisi, in Belleten 28/111 (1964), 419-438.

Küçükdağ, Y., II. Bayezid, Yavuz ve Kanuni devirlerinde Cemali ailesi, Istanbul 1995.

Leal, K.A., The Balat district of Istanbul: Multiethnicity on the Golden Horn, in S. Miller 
and M. Bertagnin (eds.), The architecture and memory of the minority quarter in the Muslim Mediterranean city, Cambridge, MA 2010.

Lowry, H.W., The shaping of the Ottoman Balkans, 1350-1550: The conquest, resettlement, and infrastructural development of northern Greece, Istanbul 2008.

Necipoğlu, G., The age of Sinan: Architectural culture in the Ottoman Empire, London 2005.

Oğuz, Z., Multi-functional buildings of the T-type in Ottoman context: A network of identity and territorialization, MA thesis, Middle Eastern Technical University 2006.

Öngören, R., Osmanlılar'da tasavvuf: Anadolu'da Sufiler, devlet ve ulema (xvI. yüzyıl), Istanbul 2000.

Pancaroğlu, O., Devotion, hospitality and architecture in medieval Anatolia, in SI 108 (2013), 48-81.

Pelidija E. and Emecen F., Îsâ Bey, in TDVIA, xii, 475-476.

Rossi, A., Architecture of the city, Cambridge, MA 1984.

Selçuk, İ., Suggestions on the social meaning and functions of akhi communities and their hospices in medieval Anatolia, in P. Blessing and R. Goshgarian (eds.), Architecture and landscape in medieval Anatolia, Edinburgh 2017, 95-113.

Singer, A., Imarets, in C. Woodhead (ed.), The Ottoman world, London and New York 2012, 72-85.

Singer, A., Mapping imarets, in N. Ergin et al. (eds.), Feeding people, feeding power: Imarets in the Ottoman Empire, Istanbul 2007, 43-56.

Stavrides, T., The sultan of vezirs: The life and times of the Ottoman grand vizier Mahmud Pasha Angelovic (1453-1474), Leiden 2001.

Subrahmanyam, S., Connected histories: Notes towards a reconfiguration of early modern Eurasia, in Modern Asian studies 31 (1997), 735-762.

Tamer, V., Fatih devri ricalinden İshak Paşa'nın vakfiyeleri ve vakıfları, in Vakıflar dergisi 4 (1958), 107-124.

Tanman, B., Sinan'ın mimarisi: İmaretler, in S. Bayram (ed.), Mimarbaşı Koca Sinan: Yaşadığı çağ ve eserleri, 2 vols., Istanbul 1988, 333-353.

Tanman, B., Demir Baba, in TDVIA, ix, 150-151.

Terzioğlu, D., How to conceptualize Ottoman Sunnitization: A historiographical discussion, in Turcica 44 (2012-2013), 301-338.

Terzioğlu, D., Where 'ilm-i hă $\bar{l}$ meets catechism: Islamic manuals of religious instruction in the Ottoman Empire in the age of confessionalization, in Past and present 220 (2013), 79-114.

Terzioğlu, D., Sufis in the age of state-building and confessionalization, in C. Woodhead (ed.), The Ottoman world, London and New York 2012, 86-99.

Turan Ş. et al., Kemalpaşazâde, in TDVIA, xxv, 238-247.

Tüfekçioğlu, A., Erken dönem Osmanlı mimarisinde yazı, Ankara 2001.

Uğur, T., Selçuk (Ayasuluk) cami ve mescidleri, MA thesis, Ege Üniversitesi 2006. 
Umur, Y., Reconstructing Yenice-i Vardar: Patronage of the Evrenosoğlu family, MA thesis, Boğaziçi University 2008.

Wilde, H., Brussa, Eine Entwickelungsstätte türkischer Architektur, Berlin 1909.

Wolper, E.S., Cities and saints: Sufism and the transformation of urban space in medieval Anatolia, University Park, PA 2003.

Yıldız, S.N., From Cairo to Ayasuluk: Hāàcı Paşa and the transmission of Islamic learning to western Anatolia in the late 14th century, in JIS 25 (2014), 263-293.

Yıldız, S.N., Aydınid court literature in the formation of an Islamic identity in fourteenth-century western Anatolia, in A.C.S. Peacock and S.N. Ylldız (eds.), Islamic literature and intellectual life in fourteenth- and fifteenth-century Anatolia, Würzburg 2016, 197-242.

Yıldız, S.N., A Hanafi law manual in the vernacular: Devletoğlu Yūsuf Balıḳesrīs Turkish verse adaptation of the Hidāya-Wiqāya textual tradition for the Ottoman Sultan Murad II (824/1424), in BSOAS 80/2 (2017), 283-304.

York, N., Imarets, Islamization and urban development in Sarajevo, 1461-1604, in Ergin et al., (eds.), Feeding people, 81-94.

Yüksel, I.A., Osmanlı mi'mârîsinde II. Bayezid ve Yavuz Selim devri, 886-926/1481-1520, Istanbul 1983 .

Yürekli, Z., Architecture and hagiography in the Ottoman Empire: The politics of Bektashi shrines in the classical age, Farnham 2012.

Yürekli, Z., Architectural patronage and the rise of the Ottomans, in F.B. Flood and G. Necipoğlu (eds.), A companion to Islamic art and architecture, 2 vols., Hoboken, NJ 2017, 733-754. 